\title{
HEAVY MINERALS IN SEDIMENTS FROM THE MOŠNICA CAVE: IMPLICATIONS FOR THE PRE-QUATERNARY EVOLUTION OF THE MIDDLE-MOUNTAIN ALLOGENIC KARST IN THE NÍZKE TATRY MTS., SLOVAKIA
}

\section{TEŽKI MINERALI V SEDIMENTIH IZ JAME MOŠNICA: IMPLIKACIJE ZA PREDKVARTARNI RAZVOJ SREDNJEGORSKEGA ALOGENEGA KRASA V NIZKIH TATRAH, SLOVAŠKA}

\author{
Katarína BÓNOVÁ ${ }^{1 *}$, Pavel BELLA², Ján BÓNA ${ }^{3}$, Ján SPIŠIAK ${ }^{4}$, Martin KOVÁČIK ${ }^{5}$, Martin KOVÁČIK ${ }^{6}$ \\ \& Lubomír PETRO ${ }^{5}$
}

\begin{abstract}
UDC 551.442(437)

Katarína Bónová, Pavel Bella, Ján Bóna, Ján Spišiak, Martin Kováčik, Martin Kováčik \& Lubomír Petro: Heavy minerals in sediments from the Mošnica Cave: Implications for the preQuaternary evolution of the middle-mountain allogenic karst in the Nízke Tatry Mts., Slovakia

The cave deposits from the Mošnica Cave located on the northern slope of the Nízke Tatry Mts. were analysed by sedimentological, petrographical and mineralogical methods. Based on mineralogical study the cave sediments are composed of dolomite, quartz, muscovite, amphibole, chlorite, calcite, Kfeldspar and plagioclase. Heavy mineral assemblage is formed by garnet, zircon, apatite, monazite, tourmaline, staurolite, rutile, titanite, epidote, sillimanite, allanite, andalusite and barite. Opaque minerals are represented by ilmenite, pyrite, magnetite, Cr-spinel, Fe-oxyhydroxides and chalcopyrite. Detailed research of chemical composition of the heavy minerals points to their source rocks formed by granitoids, amphibolites and amphibolite gneisses representing the crystalline basement and probably by Triassic cover sediments of the Lúžna Formation. Presence of the allochthonous minerals in the cave from metamorphic complex recently occurred on the opposite southern slope of the Nízke Tatry Mts. indicates a past larger catchment area of the allogenic karst of Mošnica Valley on the pre-Quaternary less dissected terrain. A change of watershed boundary leading through the central range of the Nízke Tatry Mts. was probably connected with the tilting of this mountain range
\end{abstract}

\begin{abstract}
Izvleček
UDK 551.442(437)

Katarína Bónová, Pavel Bella, Ján Bóna, Ján Spišiak, Martin Kováčik, Martin Kováčik \& L’ubomír Petro: Težki minerali $v$ sedimentih iz jame Mošnica: implikacije za predkvartarni razvoj srednjegorskega alogenega krasa v Nizkih Tatrah, Slovaška

Jamski sediment iz jame Mošnica, ki se nahaja na severnem pobočju Nizkih Tater, so bili analizirani z sedimentološkimi, petrografskimi in mineraloškimi metodami. $\mathrm{Na}$ podlagi mineraloških raziskav jamske sedimente sestavljajo dolomit, kremen, muskovit, amfibol, klorit, kalcit, K-glinenec in plagioklaz. Težko mineralno frakcijo predstavljajo granat, cirkon, apatit, monazit, turmalin, staurolit, rutil, titanit, epidot, sillmanit, allanit, andaluzit in barit. Neprozorni minerali so zastopani z ilmenitom, piritom, magnetitom, Cr-spinelom, Fe-oksihidroksidi in halkopiritom. Detajlna analiza kemične sestave težkih mineralov je nakazala njihov izvor iz granitov, amfibolitov in amfibolitnih gnajsov, ki predstavljajo kristalinsko podlago in iz triasnih krovnih sedimentov Lužna formacije. Prisotnost alohtonega materiala iz metamorfnega kompleksa, ki so bili najdeni v jami na nasprotnem južnem pobočju Nizkih Tater nakazuje nekdanje večje območje porečja alogenega krasa v dolini Mošnice na predkvartarnim manj razčlenjenim terenu. Sprememba meje porečja, ki poteka skozi osrednje območje Nizkih Tater je bila verjetno povezana z nagibanjem tega pogorja proti severu zaradi kompresijskega tektonskega režima $\mathrm{v}$ času poznega terciarja.
\end{abstract}

\footnotetext{
${ }^{1}$ Institute of Geography, Faculty of Science, Pavol Jozef Šafárik University in Košice, Jesenná 5, 04001 Košice, Slovakia;

*e-mail: katarina.bonova@upjs.sk

${ }^{2}$ State Nature Conservancy of the Slovak Republic, Slovak Caves Administration, Hodžova 11, 03101 Liptovský Mikuláš \& Department of Geography, Pedagogical Faculty, Catholic University, Hrabovská cesta 1, 03401 Ružomberok, Slovakia; e-mail: pavel.bella@ssj.sk

${ }^{3}$ Kpt. Jaroša 780/13, 04022 Košice, Slovakia; e-mail: janobona@hotmail.com

${ }^{4}$ Department of Geography, Geology and Landscape Ecology, Faculty of Natural Sciences, Matej Bel University, Tajovského 40, 97401 Banská Bystrica, Slovakia; e-mail: jan.spisiak@umb.sk

${ }^{5}$ State Geological Institute of Dionýz Štúr, Regional centre - Košice, Jesenského 8, 04001 Košice, Slovakia;

e-mail: martin.kovacik@geology.sk, lubomir.petro@geology.sk

${ }^{6}$ State Geological Institute of Dionýz Štúr, Mlynská dolina 1, 81704 Bratislava, Slovakia; e-mail: mato.kovacik@geology.sk

Received/Prejeto: 19.11.2013
} 
towards the north, in the compression regime during the Late Tertiary.

Key words: cave sediments, slackwater facies, mineral composition, provenance, allogenic karst, Mošnica Cave, Nízke Tatry Mts.
Ključne besede: jamski sedimenti, "slackwater" facies, mineralna sestava, provenienca, alogeni kras, jama Mošnica, Nízke Tatre.

\section{INTRODUCTION}

\begin{abstract}
Allochthonous cave sediments prove an important record of sedimentary phases of cave development and paleogeographical evolution of landforms in the adjacent area. Use of heavy mineral associations for the interpretation of source areas in the Western Carpathians performed Kicińska and Głazek (2005) in the karst of Belianske Tatry Mts., Orvošová et al. (2006) in the karst of Nízke Tatry Mts., Bónová et al. (2008) in the Slovak Karst and Bónová et al. (2014) in the karst of Chočské Foothills. The contribution presents the mineralogicalpetrological and sedimentological characteristics of al-
\end{abstract}

lochthonous sediments from the Mošnica Cave as one of the highest-lying subhorizontal caves in the allogenic karst of the Demänová Hills (Nízke Tatry Mts.). The aim of the research is based on the heavy mineral associations and their chemical composition to identify the source rocks and the areas of their transport into the cave, as well as to point out to the importance of the mineralogical and petrological research of cave sediments for the reconstruction of the pre-Quaternary evolution of the middle-mountain allogenic karst on the northern slope of the Nízke Tatry Mts.

\section{LOCATION}

The Mošnica Cave is the most important cave in the western part of Demänová Hills that belong to the Ďumbierske Tatry Mts. (geomorphologic subunit of the Nízke Tatry Mts.). The cave is located in the slope of Skoková Valley on the right side of the Mošnica Valley which lies west of the well-known Demänová Valley (Fig. 1A). The Mošnica Valley leads from Bôr (1,887.6 m a.s.l.) to the north and its mouth into the Liptov Basin is at $715 \mathrm{~m}$ a.s.l. The main entrance to the Mošnica Cave is at the altitude of $1,060 \mathrm{~m}$, $223 \mathrm{~m}$ above the Mošnica river bed.

\section{GEOLOGICAL AND GEOMORPHOLOGIC SETTINGS}

The Dumbierske Tatry Mts. represent the core mountain which consists of crystalline basement and its cover units. The Dumbier crystalline complex is composed of pre-Mesozoic granitoids, high-grade metamorphic rocks (orthogneisses, granulites, paragneisses), metabasic and metaultramafic rocks (Spišiak \& Pitoňák 1990; Biely et al. 1992). The metamorphic rocks are intruded by Carboniferous granitoid pluton which consists of several types (Ďumbier, Prašivá and Latiborská hola), ranging from tonalite to granite composition. Magmatic rocks occur in the northern part of the area, whereas metamorphic ones form its southern part with a transitional zone of migmatites at their contact (Bezák \& Klinec 1983; Fig. 2). Preserved remnants of the sedimentary envelope, in places deeply folded into the crystalline, are built by Lower
Triassic (i. e. quartzites), less frequently Middle Triassic rocks (rauhwackes). Western and northern parts of the Tatricum are overlain by Mesozoic units of the Fatricum represented by the Krížna Nappe (Biely et al. 1992; Bezák et al. 2008).

\section{MOŠNICA VALLEY}

The southern part of the valley is formed by Tatricum - crystalline basement with autochthonous sedimentary envelope (Fig. 2). The crystalline rocks are presented mainly by muscovite-biotite granodiorites to granites (Prašivá type), on the left side of the valley with small islet positions of quartz diorite to diorite. Biotite tonalites to granodiorites (Ďumbier type) pass from the neighbouring Demänová Valley (Biely et al. 1992). A smoothly 


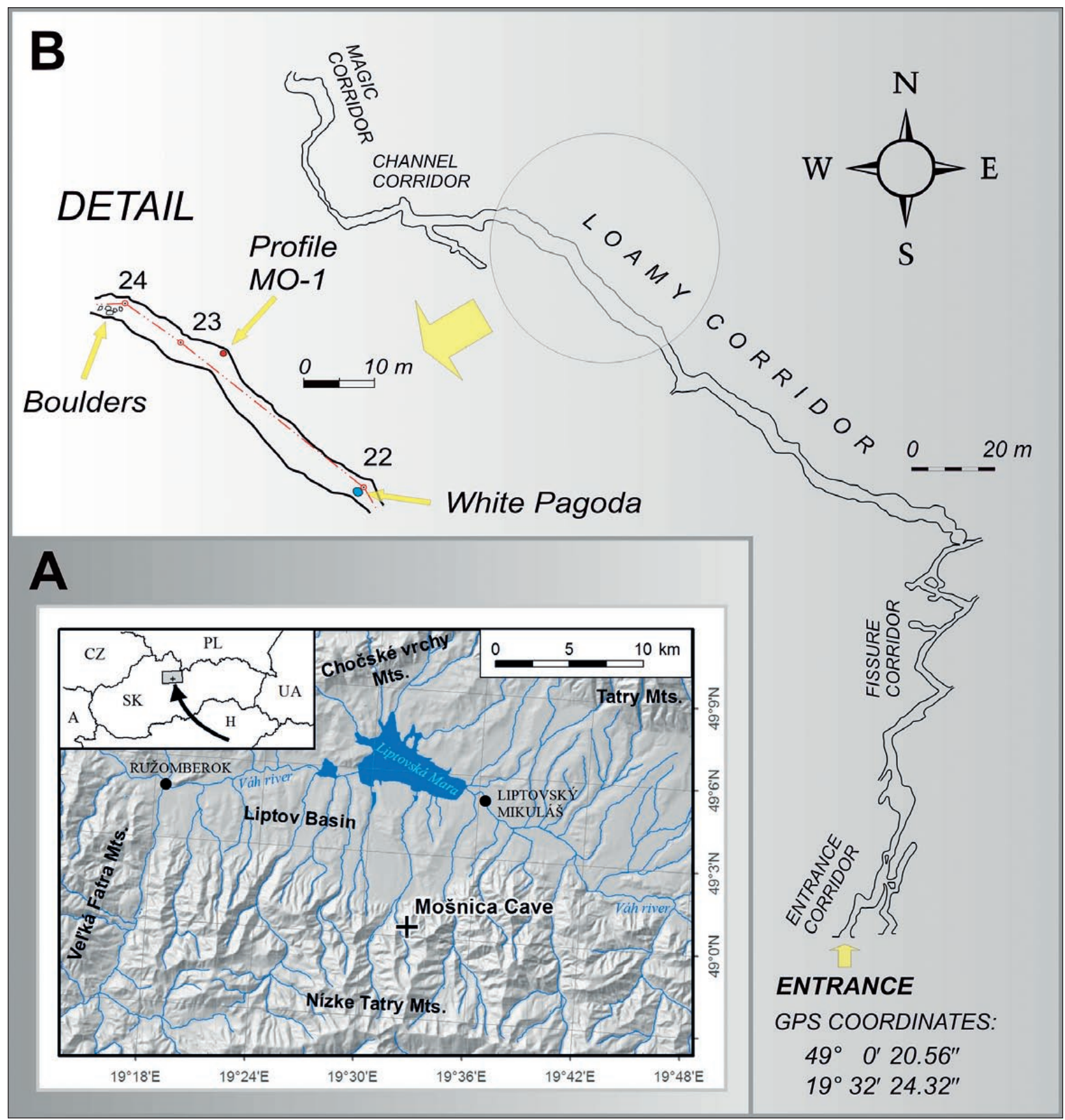

Fig. 1: Mošnica Cave. Location map (A), longitudinal projection (B - measured by Droppa 1950).

modelled relief on the crystalline rocks is partially dissected by glacier landforms from the Late Pleistocene (Škvarček 1978). The Lower Triassic sedimentary envelope performs in a narrow strip on the northern edge of the crystalline basement. Its basal part is represented by Lúžna Formation (Scythian) involves coarse-grained to arkosic sandstones and sandstone quartzites. Werfenian beds (Scythian) consist of less thick strata of colourful shales with rare sandstone inserts. The sedimentary en- velope contains also the thick strip of the Middle Triassic rauhwackes (Bujnovský 1975).

The northern part of the Mošnica Valley is build by carbonate complex of Krížna Nappe that consists of Middle Triassic (Anisian) Gutenstein limestones and overlying layered massive dolomites (Ladinian; Fig. 2). The karst of Mošnica Valley presents a karst of monoclinal ridges strongly conditioned by a fault-nappe structure. The narrowest part of the valley presents a karst 


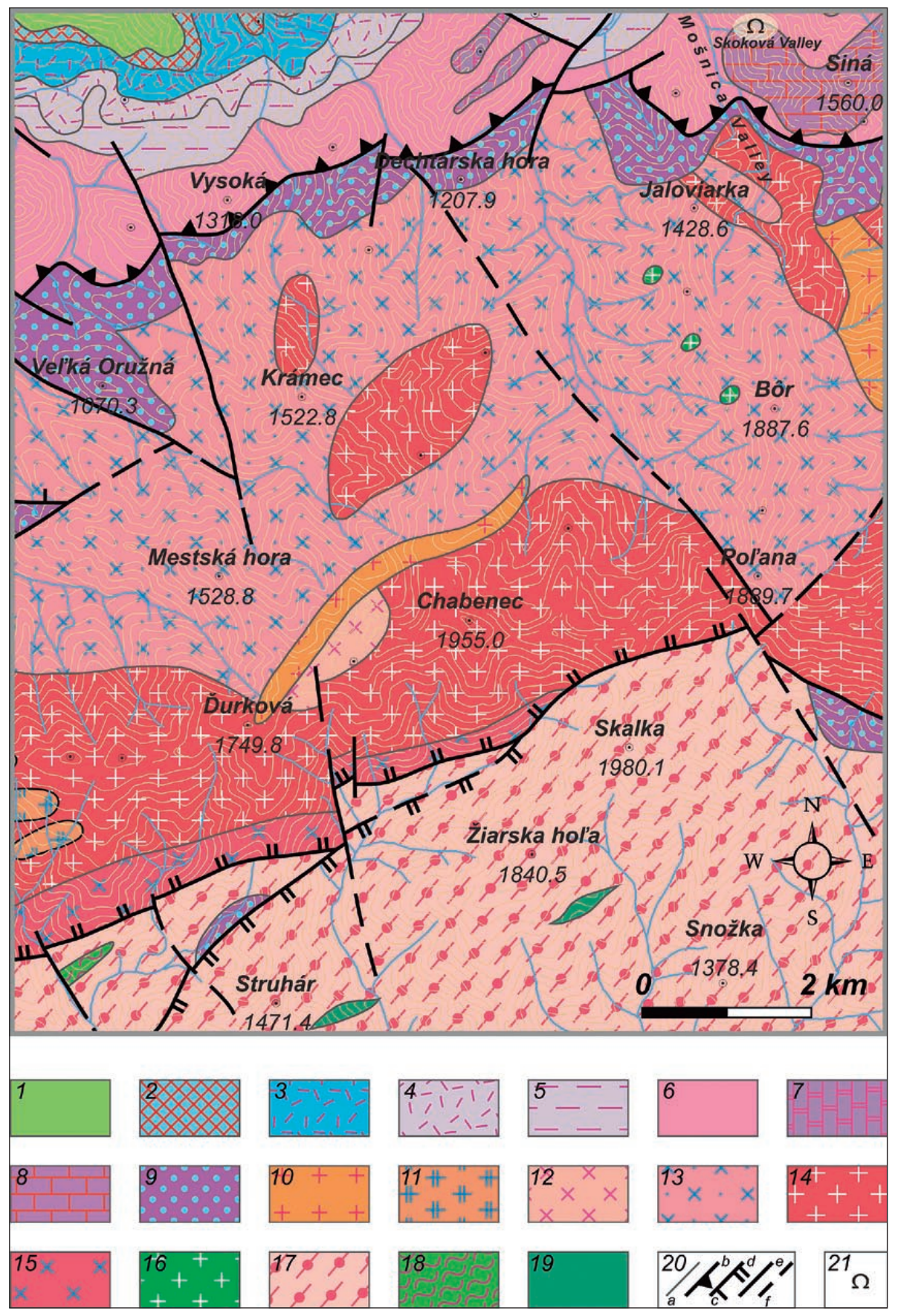

Fig. 2: Geological map of the Mošnica Valley and its surrounding area (according to Bezák et al. 2008, partly modified). Explanations: Fatricum: Jurassic-Cretaceous: 1 - Mraznica Fm.: grey marly limestones, marlstones, marly shales; Osnica Fm.: pale-grey Calpionella limestones, marly shales; Jurassic: 2 - Jasenina Fm.: clayey Sacoccoma-aptychus limestones; Ždiar Fm.: radiolarian limestones and radiolarites; Triassic-Jurassic: 3 - siliceous fleckenmergel, Adnet and Hierlatz limestones, Allgäu Fm., Kopienec Fm., Fatra Fm.; Triassic: 4 - Fatra Fm.: black Lumachella, marly and coral limestones; 5 - Carpathian Keuper; 6 - Ramsau dolomites; 7 - Podhradie limestones; 8 - Gutenstein limestones; Tatricum: T: 9 - Lúžna Fm.: quartzites, quartzose sandstones, greywackes, conglomerates, variegated sandy shales and intercalations of sandstones (Early Triassic); Tatricum crystalline units: Late Devonian-Early Carboniferous: 10 - leucocratic granites, locally porphyritic; 11 - biotite to two-mica granites to granodiorites; 12 - porphyric biotite granites to granodiorites; 13 - porphyric biotite to two-mica granodiorites to granites; 14 - biotite tonalities to granodiorites; 15 - hybridic non-homogenous granodiorites to tonalities; 16 - diorites; Proterozoic?-Paleozoic: 17 - orthogneisses and migmatites with banded and eyed structures with amphibolites and paragneisses layers; 18 - amphibolitic gneisses; 19 - amphibolites; 20 - a) geological boundaries, b) main Paleoalpine tectonic units boundaries, c) partial tectonic units boundaries, d) other tectonic lines, e) unspecified faults, $f$ ) assumed faults; 21 - cave. 
gorge formed by the incision of allochthonous Mošnica Stream, partly sinking into the underground.

The northernmost part of the valley is formed by Upper Triassic partly silicified stratified dolostones (Carnian-Norian) and the Carpathian Keuper Formation (Norian) consisting of yellowish layered dolostones with interlayers of red and green shales and shales with junk inserts of Keuper-dolostone (Bujnovský 1975). Other upper strata of Krížna Nappe are covered by sedimentary rocks of Central Carpathian Paleogene Basin (Gross et al. 1980). Quaternary formations are formed by glacial, glacifluvial, fluvial and deluvial sediments.

\section{BASIC MORPHOLOGICAL FEATURES AND PROBLEMATICS OF CAVE GENESIS}

The Mošnica Cave is formed in the Middle Triassic Gutenstein limestones of Krížna Nappe. It reaches a length of $450 \mathrm{~m}$, vertical range about $10 \mathrm{~m}$ (Fig. 1B) and dominantly consists of horizontal to subhorizontal corridors (Droppa 1950; Bella 1988; Bella \& Urata 2002).

According to Droppa (1950) this cave originated by meteoric waters infiltred though enlarged fissures during intensive precipitations. Based on the sharp-edged particles of fine-grained allochthonous cave sediments he considered their aeolian transport on the surface above the cave from an uplifted and denudated crystalline basement of the central ridge of the Nízke Tatry Mts. and their washing into the cave by rainwaters through enlarged fissures. Droppa (1973) classified the Mošnica Cave as a fissure-corrosion cave.

Oval shapes sculpted by flowing water are visible in the Loamy Corridor and some other parts. The remnant of wall scalloped surface in the Entrance Corridor prove the direction of past water flow into the cave, probably allochthonous waters of the Mošnica paleostream (wall morphology of the corridor was largely remodelled by frost weathering). Primary cavities originated in the phreatic zone (oval corridors, ceiling pockets and irregular hollows; Fig. 3A and B). During younger developmental stage they were remodelled in the shallow phreatic zone after a decrease and following stability of water table (water table wall notches; Fig. 3C). Finally, the rocky floors of Channel and Magic corridors were incised by vadose water flow (meandering floor channel). In the vadose development stage vertical wall grooves originated by corrosion caused by rainwaters seeping along steep fissures, and several varieties of flowstones and dripstones, mainly pagoda-like stalagmites (Fig. 3D), precipitated from the mineralized water solutions. Some cave parts are remodelled by rock breakdown (Bella 1988; Bella \& Urata 2002).

Based on oval shapes of several corridors, significantly prevailing horizontal corridors and position in height Bella (1988) considered the Mošnica Cave as an inactive river modelled cave originated during a tectonic stability, probably synchronously with the formation of a planation surface on the north side of Nízke Tatry Mts., remnants of which are of about $1000 \mathrm{~m}$ a.s.l. (denudation niveau N-III; Dinev 1942). Its height position more or less corresponds to the Late Pliocene River level that is observed in the Demänová Hills at altitudes of 1000$1050 \mathrm{~m}$, eventually 950-1000 m a.s.l. (Droppa 1972; Bella 2001, 2002).

Considering a developmental correlation of cave levels with terraces of Váh River in the Liptov Basin, Orvoš and Orvošová (1996) rate the Mošnica Cave to the terrace T-XIa (in the relative high of 220-240 m from the recent river bed), which appertain to Reuverian A stage of the North West European stages. Fine-grained clastic sediments in the Loamy Corridor have normal polarity, they were deposited in stagnant water probably during the Gauss paleomagnetic epoch, i.e. before more than $2.588 \mathrm{Ma}$ (Bosák et al. 2004; Kadlec et al. 2004).

Lower situated cave levels in the valleys of Demänová Hills including the Mošnica Valley) are correlated with the development of Quaternary river terraces (Droppa 1966, 1972; Orvoš \& Orvošová 1996; Bella et al. 2011). 

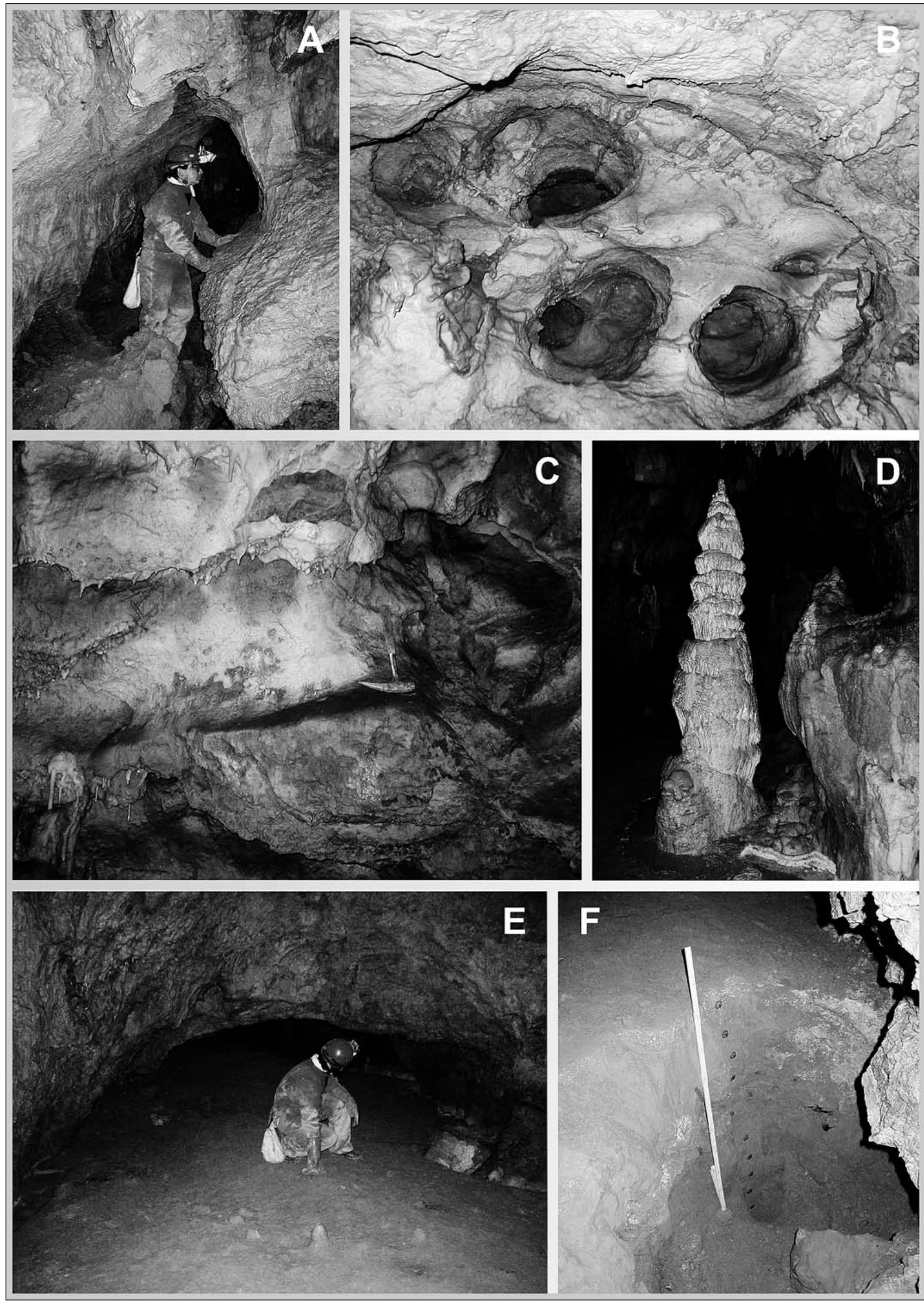

Fig. 3: Mošnica Cave, Loamy Corridor and its north-west adjacent part: A - prevailing phreatic morphology of outflow channel; $B$ - ceiling pockets; $C$ - epiphreatic lateral wall notch; $D$ - stalagmite named the White Pagoda $(2.4 \mathrm{~m}$ high); $E$ - corridor floor covered by fine-grained sediments; F-studied sedimentary profile (Photo: P. Bella). 


\section{MATERIALS AND METHODS}

The sedimentological profile located in the Loamy Corridor about $215 \mathrm{~m}$ above the bottom of the Mošnica Valley was studied (excavation up $1 \mathrm{~m}$ depth; Fig. $1 \mathrm{~B}$ and $3 \mathrm{~F}$ ). Four samples (MO-1A to MO-1D) weighing 2-3 kg were collected for the granulometric analysis and preparation of the heavy mineral concentrates. Preparation of the samples was carried out in the laboratories of the Department of Applied Technology of Raw Minerals (State Geological Institute of Dionýz Štúr, Regional centre - Košice, Slovakia). Heavy mineral concentrate was obtained by the standard methods from the 0.02 to $0.063 \mathrm{~mm}$ size fraction and by the final separating in the heavy liquid, tetrabromethane with $\mathrm{D}=2.96 \mathrm{~g} / \mathrm{cm}^{3}$. Concentrates were qualitatively and quantitatively evaluated with the focus on translucent heavy minerals. Total of 300 to 350 grains were optically evaluated.

Garnet, amphibole, tourmaline, spinel and Fe-Ti oxides were analysed in a sample of polished thin sections by an electron microanalyzer CAMECA SX 100 (State Geological Institute of Dionýz Štúr, Bratislava) with the WDS method at accelerating voltages of $15 \mathrm{kV}$, beam current of $20 \mathrm{nA}$ and electron beam diameter of $5 \mu \mathrm{m}$. To measure the concentrations of various elements were used following natural and synthetic standards: fluorapatite (P $K \alpha)$, orthoclase $(\mathrm{Si} K \alpha), \mathrm{TiO}_{2}(\mathrm{Ti} K \alpha), \mathrm{Al}_{2} \mathrm{O}_{3}(\mathrm{Al} \mathrm{K \alpha}), \mathrm{Cr}$ $(\mathrm{Cr} K \alpha)$, fayalite $(\mathrm{Fe} K \alpha)$, rhodonite $(\mathrm{Mn} K \alpha)$, forsterite $(\mathrm{Mg} K \alpha)$, wollastonite $(\mathrm{Ca} K \alpha), \mathrm{SrTiO}_{3}(\mathrm{Sr} K \alpha)$, albite $(\mathrm{Na} K \alpha), \mathrm{LiF}(\mathrm{F} \mathrm{K \alpha})$ and $\mathrm{NaCl}(\mathrm{Cl} \mathrm{K \alpha})$. Crystallochemical formula of garnet was normalized to 12 oxygens and conversion of an iron valence $\left(\mathrm{Fe}^{3+}\right.$ and $\left.\mathrm{Fe}^{2+}\right)$ according to ideal stoichiometry. Analysed points for tourmaline have been located in the centre, in the rim and on the margin of the grains. Tourmaline structural formula was calculated on the base of 24.5 oxygens (without boron); amphibole structural formula on the basis of 23 oxygens by calculation procedure given in Leake et al. (1997). Analyses of spinel were calculated on the basis of 3 cations. $\mathrm{Fe}^{2+}$ and $\mathrm{Fe}^{3+}$ in spinel were allocated according to the ideal stoichiometry. In Fe-Ti oxides $\mathrm{FeO}_{\text {tot }}$ was distributed into $\mathrm{FeO}$ and $\mathrm{Fe}_{2} \mathrm{O}_{3}$ sensu Dropp (1987) and structural formula was computed on the base of 4 oxygens.

Cathodoluminescence was used for observe the zircon zoning. It was carried out in the same instrument at accelerating voltage of $8 \mathrm{kV}$ and beam current of $1 \times 10^{-3} \mathrm{nA}$.

\section{RESULTS}

\section{DESCRIPTION OF THE CAVE DEPOSITS}

Two lithofacies have been recorded in the profile (Fig. 4; excavated profile does not attain to the rocky floor): 1) gray silty clay with thickness up to $50 \mathrm{~cm}, 2$ ) rusty gray silty clay with thickness up to the $10 \mathrm{~cm}$. Both lithofacies alternate in the vertical direction several times and boundaries between them are gradual.

Gray silty clay is lithofacies of standing or stagnant water (slackwater facies, sensu Gillieson 1996; Bosch \& White 2004). The lithofacies have been created by deposition of fine particles (clay and silt) transported into the cave system as suspended load in muddy floodwater. Rusty gray silty clay is probably the original gray silty clay enriched in $\mathrm{Fe}$-oxyhydroxides originated in oxidative conditions at the time the cave was not flooded and sediments have been subject of weathering. During the sedimentogenesis the clay has been sporadically supplied with speleogene material (e.g. carbonate fragments).

\section{PETROGRAFICAL AND MINERALOGICAL CHARACTERISTICS}

Allochthonous cave sediments represent the "cave loams". Based on the results of grain-size analysis they can be classified as a silt fraction (Hlaváć et al. 2004).

Dolomite is the main component of the fraction $<2 \mathrm{~mm}$ (sand fraction) in all samples. Dolomite forms usually the lithic fragments. It is an irregularly limited, transparent to translucent, white to light gray colour. Quartz is angular to rounded, usually shows a higher degree of sphericity (Powers 1953; Fig. 5). Very rounded grains of quartz were also observed in non-significant amounts (Fig. 5B). Quartz is usually translucent to white, less transparent, usually bright. Monocrystalline grains predominate over the polycrystalline ones. Muscovite has a pearly luster. It forms irregularly limited flakes (rarely pseudohexagonal tables) crumbling under the surface of [001]. Amphibole forms the subhedral fragments. It is green to dark green, partially transparent with characteristic cleavage. Calcite forms the translucent crystals derived from filling of the carbonate ruptures or lithic fragments which may be derivable from 


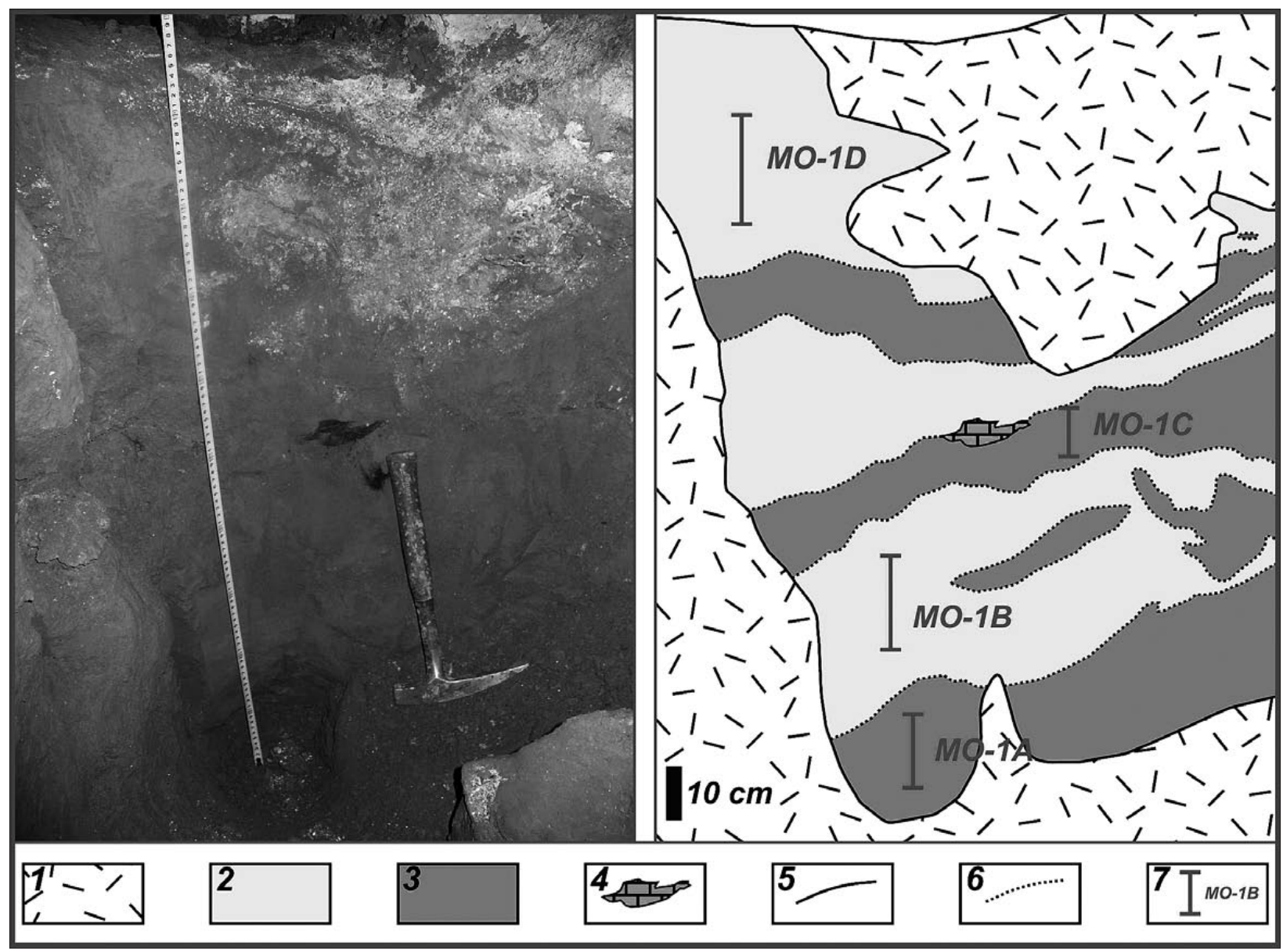

Fig. 4: Profile MO-1, Mošnica Cave: 1 - debris, 2 - gray silty clay, 3 - rusty gray silty clay, 4 - fragment of dark gray carbonate, 5 - sharp boundary between lithofacies, 6 - gradual boundary between lithofacies, 7 - location and identification of samples.

the Gutenstein beds. K-feldspar (orthoclase) forms usually pinkish irregularly limited grains or fragments with characteristic cleavage surfaces of [001] and [010]. Plagioclase is mostly white, its habitus and cleavage is similar to K-feldspar. Chlorite forms flakes crumbling under cleavage of [001]. It has green colour with glass to pearl luster.

The fraction $>2 \mathrm{~mm}$ (gravel fraction) was noticed in a minor amount and only in MO-1A (5.1 vol. \%) and MO-1C (5 vol. \%) samples. It is made up of highly angular fragments of carbonates (mainly dolomite) in diameter 5-20 $\mathrm{mm}$. The small crystals of calcite are preserved on the dolomite fragments (MO-1C sample). Individual carbonate fragments show no signs of mechanical transport. Therefore, we consider them to be autochthonous (speleogenous).

\section{HEAVY MINERALS}

The percentage abundance of heavy minerals was evaluated from all samples (Tab. 1). Apatite (up to 26.0 vol. \%) and amphibole (up to 28.6 vol. \%) prevail in the MO-1A, MO-1B and MO-1D samples. In the MO-1C sample zircon predominates over the apatite and amphibole. The quantitative differences can be justified by the differences in the size of the prepared fractions. In addition to apatite, zircon and amphibole, the heavy mineral assemblage is represented by epidote; garnet and tourmaline are found more rarely. The presence of other translucent minerals is given in Tab. 1. The opaque minerals are represented by ilmenite, pyrite, magnetite, Cr-spinel, +/- chalcopyrite and $\mathrm{Fe}$-oxides (limonite, goethite).

Amphibole. All samples are represented mainly by calcic amphiboles with $\mathrm{Ti}<0.15$ and $\mathrm{Ca}>1.5$ a.p.f.u. Based on Leake's classification (Leake et al. 1997) the magnesiohornblende is predominate (Tab. 2, Fig. 6A). Its chemical composition in the direction of the central zone to grain periphery changes marginally with $X_{M g}\left[\mathrm{Mg} /\left(\mathrm{Mg}+\mathrm{Fe}^{2+}\right)\right]$ between 0.62 to 0.84 . Some hornblendes show rimward Al-enrichment (Tab. 2), pointing to prograde metamorphism. Otherwise, the second group of Mg-hornblendes 

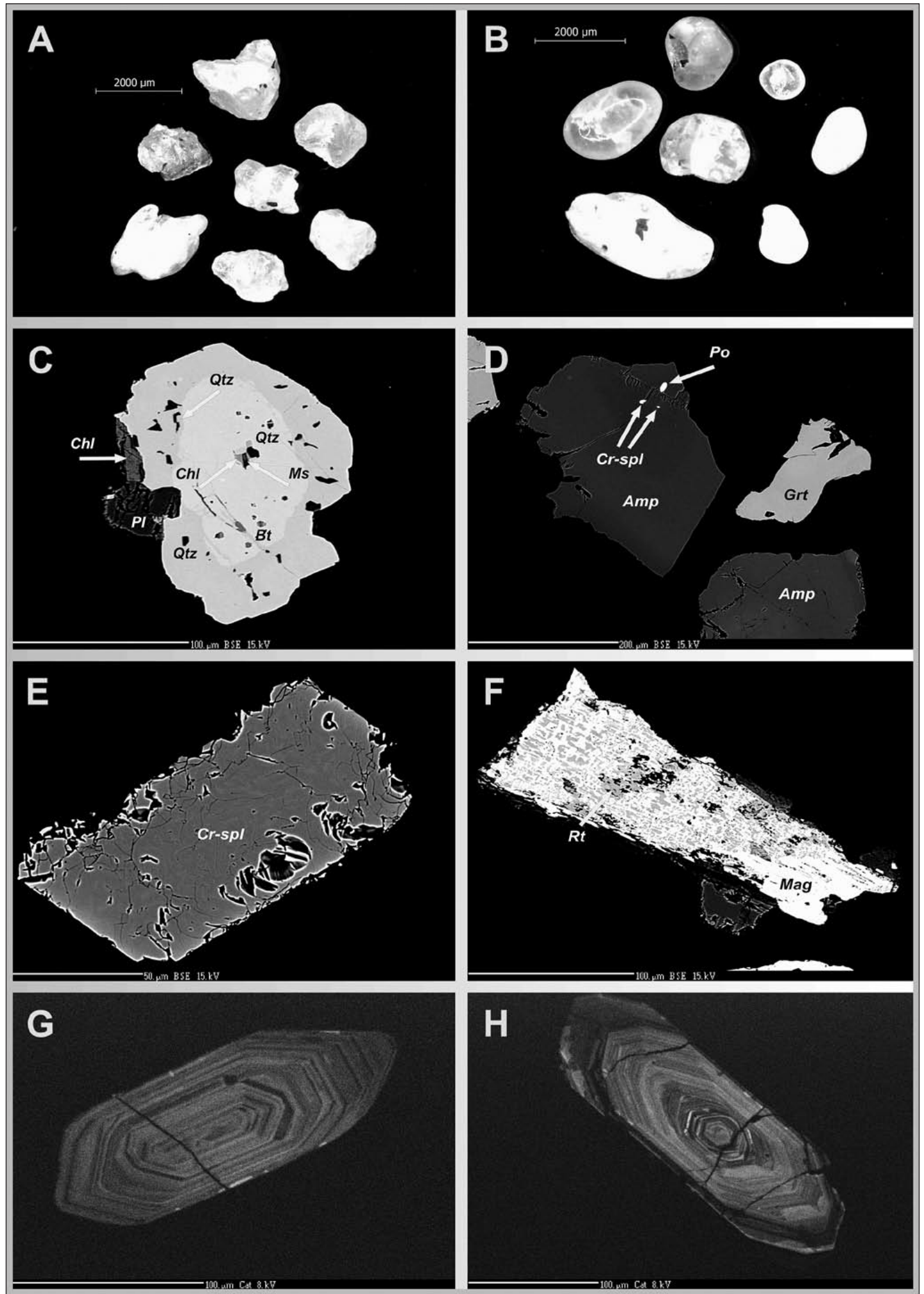

Fig. 5: Quartz: A - Angular to semi-angular clasts with a higher degree of sphericity (MO-1A); B - Rounded to very rounded clasts with the higher and lower degrees of sphericity (MO-1A); Heavy minerals (BSE images): C-inclusions of white mica (Ms), biotite (Bt), chlorite (Chl) and quartz (Qtz) in zonal garnet (MO-1A); D - inclusions of spinels (Cr-spl) and pyrhotite (Po) in hornblende (MO-1A); E - alteration process of chrome-spinel (MO-1C); F- breakdown of Ti-rich magnetite to pure magnetite (Mag) and rutile (Rt), (MO-1C); $\mathrm{G}, \mathrm{H}$ - internal texture of zircon (CL; MO-1A). 


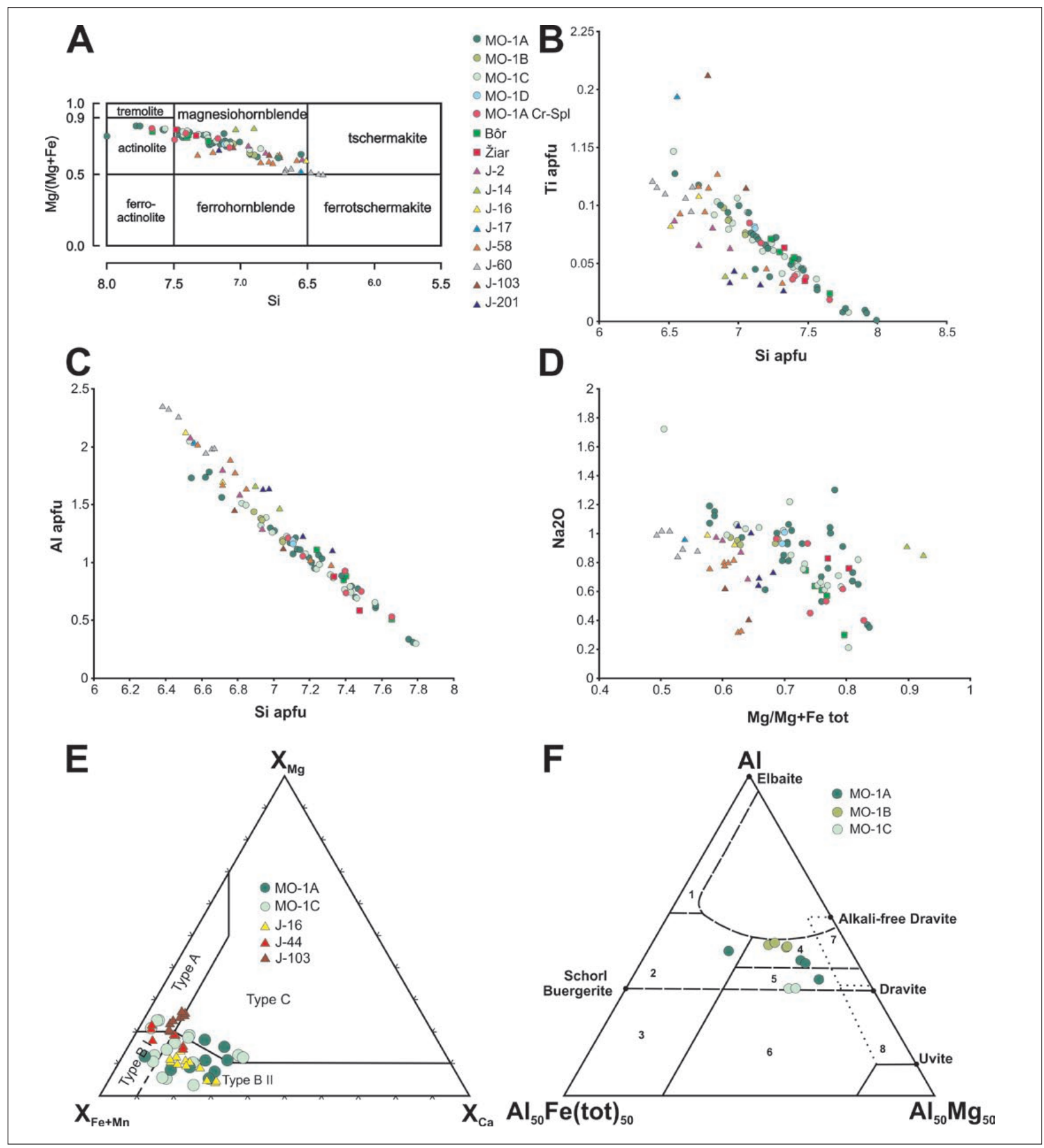

Fig. 6: A - Classification scheme of amphiboles (Leake et al. 1997) from the cave sediments (MO-1A to MO-1D), from diorites (Bôr locality - analyses from this work; Žiar Mts. - analyses from Uher \& Miko 1994) and from the different types of amphibolites and amphibolic gneisses (J-2 to J-203); B - Diagram Ti vs. Si (a.p.f.u.) for amphiboles; C - Diagram Al vs. Si (a.p.f.u.) for amphiboles; $\mathrm{D}$ - Diagram $\mathrm{Na}_{2} \mathrm{O}$ (wt. \%) vs. $\mathrm{Mg} / \mathrm{Mg}+\mathrm{Fe}$ (a.p.f.u.) for amphiboles. Locations of the J-2 to J-203 samples are publicated in Pitoňák and Spišiak (1989). E - Composition of detritic garnets in Fe + Mn-Mg-Ca ternary diagram after Morton et al. (2004) from cave sediments (MO-1A, MO-1C) and garnets from amphibolites and amphibolic gneisses (J-16, J-44 and J-103): type A - Grt from granulites; type BI - Grt from intermediate to acid igneous rocks; type B II - Grt from metasediments of amphibolite facies; type C - Grt from metabasites. F - Diagram Al-Fe-Mg for tourmalines (Henry \& Guidotti 1985). Explanations: (1) Li-rich granites; (2) Li-poor granites and aplites; $(3,6) \mathrm{Fe}^{3+}$-rich quartz-tourmaline rocks; (4) metapelites and metapsamites co-existed with Al-rich phases; (5) metapelites and metapsamites not co-existed with Al-rich phases; (7) low-Ca metaultramafites, Cr-and $\mathrm{V}$-rich metasediments; (8) metacarbonates and metapyroxenites. 
is shifted into the actinolite with simultaneously increase of $\mathrm{Si}$ and decrease of Al. Apatite, chlorite, micrometerscale wormy Cr-spinel and pyrhotite (Fig. 5D) represent the inclusions. Decreasing content of $\mathrm{Al}^{\mathrm{IV}}$ and alkalies toward to periphery of the grains indicates the temperature drooping. $\mathrm{Na}^{M(4)}$ content in $\mathrm{Mg}$-hornblende reaches a maximum value of 0.02 a.p.f.u. indicating a low-pressure environment. These grains are characterized by slightly elevated content of $\mathrm{Ti}$ and $\mathrm{Al}$ (Fig. 6B, $\mathrm{C}$ ) and compared to hornblende from igneous rocks also slightly increased content of $\mathrm{Na}$ (Fig. 6D). In addition to Mg-hornblende the presence of anthophylite has been observed (MO-1A sample), which is distinctive of the amphibolites and gneisses. Gradual change of edenite (MO-1A and MO-1C samples) to Mg-hornblende from the cores to the rims is accompanied by a decrease of $\mathrm{Al}$ content and $(\mathrm{Na}+\mathrm{K})_{\mathrm{A}}$ ratio. Edenite is typical of medium-grade metamorphites and/or intermediate plutonic rocks.

Garnet. Detrital grains show variable chemical composition. Grossularite-almandine $\left(\operatorname{Prp}_{5-9} \operatorname{Sps}_{6-13} \mathrm{Grs}_{14-23} \mathrm{Alm}_{64-74}\right)$ indicates the metamorphism in low amphibolite facies conditions. Pyropegrossularite-almandine garnets with a minimum spessartine component $\left(\mathrm{Sps}_{0-2} \operatorname{Prp}_{11-12} \mathrm{Grs}_{29-33} \mathrm{Alm}_{53-60}\right)$ could originate from the amphibolites. Pyrope-almandine garnets $\left(\mathrm{Grs}_{2} \mathrm{Adr}_{2} \mathrm{Sps}_{7} \operatorname{Prp}_{23} \mathrm{Alm}_{66}\right)$ with low Ca component are probably derived from acidic gneisses eventually metagranites. Because of low spessartine in these grains, granites as the source rocks are excluded. Almandine-spessartine garnet ( $\mathrm{Adr}_{3} \mathrm{Grs}_{6} \operatorname{Prp}_{12} \mathrm{Alm}_{38} \mathrm{Sps}_{41}$ ) captured in the MO-1C sample can be considered the granite or granitic pegmatite. Zonal garnets represent a separate group. They are characterised by low grossularite and higher pyrope and almandine components in the central zone $\left(\mathrm{Sps}_{6} \mathrm{Grs}_{6} \operatorname{Prp}_{12} \mathrm{Alm}_{77}\right)$. Marginal zone has apparently lower content of pyrope and almandine at the expense of significantly increasing grossularite one $\left(\mathrm{Sps}_{3} \operatorname{Prp}_{7} \mathrm{Grs}_{27} \mathrm{Alm}_{63}\right)$. Inclusions of white mica, biotite, chlorite and quartz located mainly in the centre of grains are characteristic. S-shaped trails of quartz and biotite are typical of the rims (Fig. 5C). However, these "inclu- sions" were probably connected with matrix in parental rock by fractures and these were related to fluid influx during the metamorphic event. The sharp change in the composition of the garnet i.e. increase of grossularite contents (from $6 \%$ in the centre of the grain to $27 \%$ in the margin), as well as in the considerable decrease of $\mathrm{Mg}$ content and increase of the $\mathrm{Fe} /(\mathrm{Fe}+\mathrm{Mg}$ ) value are significant for retrograde zoned garnets occurring in mica schists and/or gneisses (Korikovsky et al. 1988; Méres \& Hovorka 1991). We ascribe the metamorphic genesis (probably lower amphibolite facies) for spessartine-almandine garnet $\left(\operatorname{Prp}_{8} \mathrm{Grs}_{15} \mathrm{Sps}_{20} \mathrm{Alm}_{57}\right)$ in which grossularite component dominates in the peripheral zone $\left(\operatorname{Prp}_{5} \mathrm{Sps}_{18} \mathrm{Grs}_{27} \mathrm{Alm}_{50}\right)$. REE-epidote and quartz inclusions are restricted to the grain's core, titanite is restricted to its rim. Figure 6E illustrates the chemical composition of the investigated garnets from the cave sediments and the comparative analysis of garnets from amphibolic rocks of the Dumbier crystalline basement.

Tourmaline. Tourmalines belong to the alkali ones with low to moderate $\mathrm{Ca}$ content. They are rather scarce minerals and correspond to a schorl-dravite, rarely dravite. According to the classification indicating the tourmaline origin (Henry \& Guidotti 1985), they were derived from metapelites and metapsamites saturated or unsaturated by $\mathrm{Al}$, respectively (Fig. 6F). Zonal character of tourmaline is demonstrated by the decreasing of ${ }^{\mathrm{Y}} \mathrm{Fe}$ ratio and simultaneously increasing of $\mathrm{Ca}$ amount towards the marginal zones (Tab. 2). It indicates the progressive metamorphism. There are also reverse zonal grains which may involve a different source rocks or they may represent the grains without the outer rims due to transport. We recorded the inherited core of the schorl composition (MO-1A sample) indicating an origin in $\mathrm{Li}^{-}$ poor granitoids (l. c.). Its outer rim originated from the metasedimentary environment. Summarizing, each of tourmalines is most likely of metasedimentary origin.

Spinel group and $\mathrm{Fe}-\mathrm{Ti}$ oxides. $\mathrm{Cr}$-spinel forms a grain (MO-1C sample) corresponds to alumochromite (Stevens 1944) or chromite (Deer et al. 1992) with $\mathrm{Cr} \#=(0.72-0.71), \mathrm{Fe} \#=(0.52-0.61)$ and $\mathrm{Mg} \#=$ (0.48-0.39) from the centre to the rim, respectively. BSE

Tab. 1: Heavy mineral assemblage of cave sediments from the Mošnica Cave. Abbreviations of minerals sensu Kretz (1983).

\begin{tabular}{|c|c|c|c|c|c|c|c|c|c|c|c|c|c|c|c|c|c|c|}
\hline 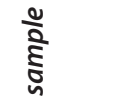 & ثั & $\stackrel{\mathbf{N}}{\mathbf{N}}$ & $\stackrel{2}{\gtrless}$ & $\stackrel{N}{\Sigma}$ & 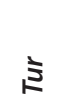 & $\stackrel{\square}{\sim}$ & $\frac{\varrho}{\xi}$ & $\stackrel{\pi}{\approx}$ & $\mathbf{E}$ & ㅂํ & $\overline{\bar{n}}$ & 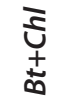 & $\bar{\hbar}$ & $\stackrel{5}{\frac{\varepsilon}{x}}$ & $\frac{7}{8}$ & ธి & 范 & $\frac{\tilde{\Xi}}{\tilde{\Xi}}$ \\
\hline MO-1A & 1.5 & 15.9 & 26.0 & 2.1 & 0.9 & - & 24.2 & 0.3 & 0.3 & 10.3 & 0.3 & 4.2 & - & - & 1.8 & 9.1 & 2.4 & 0.9 \\
\hline MO-1B & - & 2.3 & 12.5 & - & 0.6 & 0.6 & 28.6 & 1.7 & - & 12.2 & - & - & 1.5 & 0.3 & - & 36.7 & 0.9 & 2.0 \\
\hline MO-1C & 1.5 & 42.3 & 9.6 & 0.9 & 0.6 & - & 8.2 & 0.6 & - & 4.4 & 0.3 & - & - & - & - & 30.6 & - & 1.1 \\
\hline MO-1D & 2.5 & 1.3 & 24.8 & - & - & - & 23.2 & - & - & 13.2 & - & 0.9 & - & 0.9 & - & 26.7 & 3.4 & 3.1 \\
\hline
\end{tabular}


image illustrates the alteration products of chrome-spinel (Fig. 5E). Dark areas reflect the Mg-rich and Fe-poor composition of the core relative to the light coloured altered rim due to replacement $\mathrm{Mg}^{2+}$ by $\mathrm{Fe}^{2+}$. $\mathrm{Mn}$ and $\mathrm{Zn}$ show no variation from core to rim. High content of $\mathrm{TiO}_{2}$ (2.74 wt. \%) combined with a low proportion of $\mathrm{Fe}^{2+} / \mathrm{Fe}^{3+}=2.1$ indicates its volcanic origin (Lenaz et al. 2000). Cr-spinels enclosed in Mg-hornblende exhibit the different character. According to Stevens' (1944) classification these spinels are concerned as ferritchromite with a low $\mathrm{Al}_{2} \mathrm{O}_{3}$ content (3.57-4.70 wt. \%). It may indicate the subsolidus co-precipitation spinel and amphibole, rather than the formation of spinel by exolution from Al-rich amphibole. Within amphibole's profile the $\mathrm{Cr}_{2} \mathrm{O}_{3}$ content remains unchanged or changes from grain's core to rim, respectively.

Beyond, ferritchromite is usually attributed to the effects of low to medium grade metamorphism up to lower amphibolite facies (Farahat 2008; Xuan Thanh et al. 2011). Mn and $\mathrm{Zn}$ show high content and introduced into spinel during alteration and metamorphism. Based on very low $\mathrm{Mg} \#=(0.005-0.1)$ concomitant with high $\mathrm{Cr} \#=(0.83-0.88)$ ferritchromite is considered to be a metamorphic origin. The altered $\mathrm{Cr}$-spinel data normally have total major elements less than 99 wt. \% that is due to containing more or less water component (l. c., Tab. 2).
Several types of Fe-Ti oxides can be observed in the samples: firstly, pure magnetite $\left(\mathrm{Mag}_{99.9} \mathrm{Usp}_{0.1}\right)$, which is in the concentrate of heavy minerals the most frequent, further titanomagnetite or magnetite-ulvöspinel s. s. $\left(\mathrm{Mag}_{58} \mathrm{Usp}_{42}\right)$ gradually passing into the pure magnetite $\left(\mathrm{Mag}_{97} \mathrm{Usp}_{3}\right)$ in grain's periphery. The break-down of Ti-magnetite is accompanied by the formation of rutile (Fig. 5F). Such a process of disintegration of Fe-Ti oxides has been described in the I-type granitoids from the Nízke Tatry Mts. (Broska \& Petrík 2011).

Allanite. Chemical composition of the allanite (MO-1B sample) indicates its magmatic origin which is documented by $\mathrm{Al}_{2} \mathrm{O}_{3}$ content ranging from 13.47 to 14.22 wt. \%. Allanites from primary granitic I-type magmas show around 15 wt. $\%$ of $\mathrm{Al}_{2} \mathrm{O}_{3}$ (Petrík et al. 1995).

Zircon. Zircons are characterized by a fine oscillatory zoning often without the signs of resorption. Their regular euhedral habitus indicates a primary magmatic (granitoid) source (Fig. 5G). Some zircons crystallized from the nucleus. The inherited cores in zircons are observed (Fig. $5 \mathrm{H}$ ). The grains showing the possible metaclastic origin (convolution zoning is indicative of the recrystallization processes) are rather rare in the investigative set of zircons.

\section{DISCUSSION}

\section{HEAVY MINERALS AND THEIR POSSIBLE ORIGIN}

Shapes of the heavy minerals as well as the minimum proportion of the resistant ones (zircon, tourmaline, rutile) indicate their deposition from the igneous and metamorphic crystalline rocks of the Nízke Tatry Mts. We attribute the igneous origin to the mineral association: zircon, apatite (clear euhedral to subhedral grains), titanite, allanite, ilmenite (containing 47 to $48 \mathrm{wt}$. \% of $\left.\mathrm{TiO}_{2}\right) \pm$ epidote. That mineral association is specific to the I-type granitoids (Broska \& Uher 2001). The main rock types are Dumbier and Prašivá granitoids that form the larger part of the Nizke Tatry pluton (Koutek 1931) and represent typical I-type granitoid suite (Broska \& Petrík 1993).

A main source of the tourmaline group of minerals, staurolite, rutile, chlorite, epidote, monazite with an oval to semi-oval habitus, garnet and anhedral apatite are derived mainly from metasediments. Mentioned mineral association may have issued from siliciclastics of the
Lúžna Formation and/or from the metamorphites of the Dumbier crystalline complex.

The heavy mineral association in psammite component of the Lúžna Formation consists of zircon, tourmaline, rutile, apatite, pyrite and leucoxene (Fejdiová 1977a, b). Tourmaline is substantial in the siliciclastics of the Lúžna Formation (Aubrecht 1994; Mišík \& Jablonský 2000). Tourmalines of metasedimentary origin (predominantly formed in a low grade clastic metasedimentary rocks) are considered to be exotic, their source is unknown (Aubrecht l. c.). Sporadic occurrence of garnet in the Lúžna sediments is described by Fejdiová (1989) and Aubrecht (1994).

We assume that the amphibole suite comprising the actinolite, Mg-hornblende and anthophyllite in association with epidote, pyrite, Cr-spinel ( \pm ilmenite) and garnet (almandine-grossularite) may originate in metabasites - amphibolites or amphibolitic gneisses, which are an integral part of the Nízke Tatry crystalline complex. Common Ca-amphiboles (Mg-hornblende), actinolite 
Tab. 2: Representative microprobe analyses of amphibole, tourmaline, garnet, spinel and Fe-Ti oxides (in wt. \%).

\begin{tabular}{|c|c|c|c|c|c|c|c|c|c|c|c|}
\hline $\begin{array}{l}\text { mineral } \\
\text { sample }\end{array}$ & $\begin{array}{r}A m p \\
M O-1 A\end{array}$ & & & & & & & & $M O-1 C$ & Bôr & \\
\hline & $1 c$ & $1 r$ & $2 c$ & $2 r$ & $3 c$ & $3 c / r$ & $3 r$ & $4 c$ & $1 c$ & $1 c$ & $1 r$ \\
\hline $\mathrm{SiO}_{2}$ & 49.72 & 49.22 & 51.04 & 50.50 & 52.91 & 51.81 & 53.53 & 56.47 & 43.30 & 50.32 & 54.11 \\
\hline $\mathrm{TiO}_{2}$ & 0.57 & 0.64 & 0.67 & 0.65 & 0.41 & 0.45 & 0.27 & 0.07 & 1.29 & 0.64 & 0.22 \\
\hline $\mathrm{Al}_{2} \mathrm{O}_{3}$ & 5.85 & 6.45 & 6.13 & 6.26 & 4.61 & 5.26 & 3.74 & 0.97 & 11.51 & 6.53 & 3.04 \\
\hline $\mathrm{Fe}_{2} \mathrm{O}_{3}$ & 0.77 & 1.08 & 0.00 & 0.00 & 0.00 & 0.00 & 0.00 & 0.00 & 0.00 & 0.00 & 0.23 \\
\hline $\mathrm{Cr}_{2} \mathrm{O}_{3}$ & 0.13 & 0.11 & 0.14 & 0.07 & 0.12 & 0.16 & 0.12 & 0.02 & 0.01 & 0.12 & 0.01 \\
\hline $\mathrm{MgO}$ & 15.48 & 15.14 & 17.48 & 17.36 & 18.91 & 18.27 & 19.12 & 23.54 & 9.79 & 15.82 & 18.36 \\
\hline $\mathrm{CaO}$ & 12.35 & 12.42 & 11.60 & 11.58 & 11.58 & 11.39 & 11.90 & 1.41 & 11.53 & 12.22 & 12.64 \\
\hline $\mathrm{MnO}$ & 0.33 & 0.26 & 0.20 & 0.25 & 0.25 & 0.27 & 0.21 & 0.50 & 0.28 & 0.32 & 0.26 \\
\hline $\mathrm{FeO}$ & 10.83 & 10.70 & 9.09 & 8.98 & 7.86 & 8.42 & 7.50 & 14.31 & 17.06 & 10.26 & 8.13 \\
\hline $\mathrm{NiO}$ & 0.02 & 0.00 & 0.00 & 0.02 & 0.02 & 0.01 & 0.05 & 0.01 & 0.03 & 0.00 & 0.03 \\
\hline $\mathrm{Na}_{2} \mathrm{O}$ & 0.93 & 0.81 & 1.04 & 1.00 & 0.73 & 0.91 & 0.65 & 0.12 & 1.72 & 0.75 & 0.30 \\
\hline $\mathrm{K}_{2} \mathrm{O}$ & 0.48 & 0.53 & 0.14 & 0.11 & 0.08 & 0.09 & 0.05 & 0.00 & 0.54 & 0.46 & 0.13 \\
\hline $\mathrm{Cl}$ & 0.03 & 0.01 & 0.01 & 0.03 & 0.00 & 0.00 & 0.02 & 0.00 & 0.01 & 0.03 & 0.01 \\
\hline$F$ & 0.03 & 0.01 & 0.01 & 0.03 & 0.00 & 0.00 & 0.02 & 0.00 & 0.01 & 0.00 & 0.00 \\
\hline $\mathrm{H}_{2} \mathrm{O}$ & 2.06 & 2.06 & 2.10 & 2.08 & 2.12 & 2.10 & 2.11 & 2.14 & 1.98 & 2.07 & 2.11 \\
\hline$\Sigma$ & 99.57 & 99.43 & 99.65 & 98.92 & 99.60 & 99.14 & 99.29 & 99.56 & 99.06 & 99.55 & 99.58 \\
\hline ek. F, Cl & 0.01 & 0.00 & 0.00 & 0.01 & 0.00 & 0.00 & 0.00 & 0.00 & 0.00 & 0.01 & 0.00 \\
\hline$\Sigma(F, C l)$ & 99.56 & 99.43 & 99.65 & 98.91 & 99.60 & 99.14 & 99.29 & 99.56 & 99.06 & 99.54 & 99.58 \\
\hline $\mathrm{Si}$ & 7.213 & 7.149 & 7.271 & 7.251 & 7.471 & 7.381 & 7.571 & 7.924 & 6.535 & 7.241 & 7.657 \\
\hline $\mathrm{Al}^{\mathrm{IV}}$ & 0.787 & 0.851 & 0.729 & 0.749 & 0.529 & 0.619 & 0.429 & 0.076 & 1.465 & 0.759 & 0.343 \\
\hline$\Sigma T$ & 8.000 & 8.000 & 8.000 & 8.000 & 8.000 & 8.000 & 8.000 & 8.000 & 8.000 & 8.000 & 8.000 \\
\hline $\mathrm{Al}^{\mathrm{VI}}$ & 0.213 & 0.254 & 0.301 & 0.310 & 0.238 & 0.265 & 0.194 & 0.085 & 0.583 & 0.348 & 0.165 \\
\hline $\mathrm{Fe}^{3+}$ & 0.084 & 0.118 & 0.000 & 0.000 & 0.000 & 0.000 & 0.000 & 0.000 & 0.000 & 0.000 & 0.024 \\
\hline $\mathrm{Ti}$ & 0.062 & 0.070 & 0.072 & 0.070 & 0.044 & 0.048 & 0.029 & 0.007 & 0.146 & 0.070 & 0.024 \\
\hline $\mathrm{Cr}$ & 0.015 & 0.013 & 0.016 & 0.008 & 0.013 & 0.018 & 0.013 & 0.002 & 0.001 & 0.013 & 0.001 \\
\hline $\mathrm{Fe}^{2+}$ & 1.278 & 1.268 & 0.900 & 0.896 & 0.725 & 0.790 & 0.733 & 0.000 & 2.067 & 1.175 & 0.914 \\
\hline $\mathrm{Mg}$ & 3.347 & 3.278 & 3.712 & 3.715 & 3.980 & 3.880 & 4.031 & 4.905 & 2.202 & 3.394 & 3.872 \\
\hline$\Sigma C$ & 5.000 & 5.000 & 5.000 & 5.000 & 5.000 & 5.000 & 5.000 & 5.000 & 5.000 & 5.000 & 5.000 \\
\hline $\mathrm{Fe}^{2+}$ & 0.038 & 0.035 & 0.183 & 0.182 & 0.204 & 0.214 & 0.154 & 1.699 & 0.086 & 0.059 & 0.049 \\
\hline $\mathrm{Mn}$ & 0.041 & 0.032 & 0.024 & 0.030 & 0.030 & 0.033 & 0.025 & 0.059 & 0.036 & 0.038 & 0.031 \\
\hline $\mathrm{Ca}$ & 1.920 & 1.933 & 1.771 & 1.781 & 1.752 & 1.739 & 1.803 & 0.211 & 1.865 & 1.884 & 1.917 \\
\hline $\mathrm{Na}$ & 0.000 & 0.000 & 0.022 & 0.004 & 0.012 & 0.014 & 0.012 & 0.029 & 0.010 & 0.018 & 0.000 \\
\hline $\mathrm{Ni}$ & 0.002 & 0.000 & 0.000 & 0.002 & 0.002 & 0.001 & 0.006 & 0.002 & 0.004 & 0.000 & 0.003 \\
\hline$\Sigma B$ & 2.000 & 2.000 & 2.000 & 2.000 & 2.000 & 2.000 & 2.000 & 2.000 & 2.000 & 2.000 & 2.000 \\
\hline $\mathrm{Na}$ & 0.262 & 0.228 & 0.265 & 0.274 & 0.188 & 0.237 & 0.167 & 0.003 & 0.494 & 0.192 & 0.082 \\
\hline $\mathrm{K}$ & 0.089 & 0.098 & 0.025 & 0.020 & 0.014 & 0.016 & 0.009 & 0.001 & 0.104 & 0.085 & 0.023 \\
\hline$\Sigma A$ & 0.350 & 0.326 & 0.291 & 0.295 & 0.202 & 0.254 & 0.176 & 0.003 & 0.598 & 0.277 & 0.106 \\
\hline
\end{tabular}


Tab. 2. Continued

\begin{tabular}{|c|c|c|c|c|c|c|c|c|c|c|c|}
\hline \multirow{3}{*}{$\begin{array}{l}\text { mineral } \\
\text { sample }\end{array}$} & \multirow{3}{*}{$\begin{array}{r}\begin{array}{r}\text { Tur } \\
M O-1 A\end{array} \\
1 c \\
\end{array}$} & \multicolumn{6}{|c|}{ Grt } & \multirow{2}{*}{\multicolumn{2}{|c|}{ MO-1C }} & \multirow[b]{3}{*}{$2 c$} & \multirow[b]{3}{*}{$3 c$} \\
\hline & & & $M O-1 C$ & & & $M O-1 A$ & & & & & \\
\hline & & $1 r$ & $1 c$ & $1 r$ & & $1 c$ & $1 r$ & $1 c$ & $1 r$ & & \\
\hline $\mathrm{SiO}_{2}$ & 36.19 & 36.61 & 36.70 & 36.50 & & 37.22 & 37.84 & 38.00 & 38.20 & 36.93 & 37.69 \\
\hline $\mathrm{TiO}_{2}$ & 0.41 & 0.88 & 0.67 & 0.72 & & 0.00 & 0.08 & 0.04 & 0.04 & 0.00 & 0.00 \\
\hline $\mathrm{Al}_{2} \mathrm{O}_{3}$ & 32.85 & 31.56 & 30.54 & 30.77 & & 21.25 & 21.37 & 21.71 & 21.85 & 21.03 & 21.65 \\
\hline $\mathrm{Fe}_{2} \mathrm{O}_{3}$ & & & & & & 0.00 & 0.00 & 1.00 & 0.50 & 1.05 & 0.82 \\
\hline $\mathrm{Cr}_{2} \mathrm{O}_{3}$ & 0.00 & 0.00 & 0.01 & 0.00 & & 0.03 & 0.00 & 0.01 & 0.00 & 0.01 & 0.00 \\
\hline $\mathrm{MgO}$ & 3.93 & 9.22 & 7.88 & 8.29 & & 2.91 & 1.73 & 3.01 & 3.14 & 3.03 & 5.87 \\
\hline $\mathrm{CaO}$ & 0.36 & 1.64 & 0.58 & 0.67 & & 2.00 & 9.44 & 11.88 & 11.28 & 3.01 & 1.42 \\
\hline $\mathrm{MnO}$ & 0.02 & 0.02 & 0.00 & 0.02 & & 2.42 & 1.24 & 1.08 & 0.92 & 17.92 & 2.87 \\
\hline $\mathrm{FeO}$ & 10.45 & 4.34 & 7.27 & 6.75 & & 33.83 & 28.06 & 23.80 & 24.55 & 16.52 & 29.71 \\
\hline $\mathrm{NiO}$ & 0.00 & 0.00 & 0.00 & 0.00 & & 0.00 & 0.00 & 0.00 & 0.00 & 0.00 & 0.03 \\
\hline $\mathrm{Na}_{2} \mathrm{O}$ & 1.69 & 1.85 & 2.55 & 2.37 & & 0.03 & 0.05 & 0.00 & 0.04 & 0.05 & 0.03 \\
\hline $\mathrm{Cl}$ & 0.01 & 0.02 & 0.00 & 0.00 & & & & & & & \\
\hline $\mathrm{K}_{2} \mathrm{O}$ & 0.01 & 0.02 & 0.00 & 0.00 & & 0.00 & 0.00 & 0.00 & 0.00 & 0.00 & 0.00 \\
\hline \multicolumn{12}{|l|}{$\mathrm{H}_{2} \mathrm{O}$} \\
\hline$\Sigma$ & 85.93 & 86.16 & 86.20 & 86.09 & & 99.69 & 99.81 & 100.53 & 100.52 & 99.56 & 100.09 \\
\hline ek. F, Cl & 0.00 & 0.00 & 0.00 & 0.00 & & & & & & & \\
\hline$\Sigma(F, C l)$ & 85.93 & 86.16 & 86.20 & 86.09 & & & & & & & \\
\hline $\mathrm{Si}$ & 6.002 & 5.928 & 6.022 & 5.982 & $\mathrm{Si}$ & 3.000 & 3.010 & 2.976 & 2.985 & 2.982 & 2.978 \\
\hline $\mathrm{Al}_{\mathrm{T}}$ & 0.000 & 0.072 & 0.000 & 0.018 & $\mathrm{Ti}$ & 0.000 & 0.005 & 0.002 & 0.002 & 0.000 & 0.000 \\
\hline$\Sigma T$ & 6.002 & 6.000 & 6.022 & 6.000 & $\mathrm{Al}$ & 2.019 & 2.004 & 2.004 & 2.012 & 2.001 & 2.016 \\
\hline $\mathrm{Al}_{\mathrm{z}}$ & 6.000 & 5.951 & 5.904 & 5.923 & $\mathrm{Fe}^{3+}$ & 0.000 & 0.000 & 0.059 & 0.029 & 0.064 & 0.049 \\
\hline $\mathrm{Fe}_{\mathrm{z}}$ & 0.000 & 0.049 & 0.096 & 0.077 & $\mathrm{Cr}$ & 0.002 & 0.000 & 0.001 & 0.000 & 0.001 & 0.000 \\
\hline$\Sigma Z$ & 6.000 & 6.000 & 6.000 & 6.000 & $\mathrm{Mg}$ & 0.350 & 0.205 & 0.351 & 0.366 & 0.365 & 0.691 \\
\hline $\mathrm{Al}_{\mathrm{Y}}$ & 0.420 & 0.000 & 0.000 & 0.000 & $\mathrm{Ca}$ & 0.173 & 0.804 & 0.997 & 0.944 & 0.260 & 0.120 \\
\hline $\mathrm{Ti}$ & 0.052 & 0.107 & 0.083 & 0.089 & $\mathrm{Mn}$ & 0.165 & 0.083 & 0.072 & 0.061 & 1.225 & 0.192 \\
\hline $\mathrm{Fe}_{\mathrm{Y}}$ & 1.450 & 0.539 & 0.902 & 0.848 & $\mathrm{Fe}^{2+}$ & 2.280 & 1.867 & 1.558 & 1.604 & 1.116 & 1.963 \\
\hline $\mathrm{Mn}$ & 0.003 & 0.003 & 0.000 & 0.003 & $\mathrm{Ni}$ & 0.000 & 0.000 & 0.000 & 0.000 & 0.000 & 0.002 \\
\hline $\mathrm{Mg}$ & 0.972 & 2.225 & 1.928 & 2.025 & $\mathrm{Na}$ & 0.004 & 0.007 & 0.000 & 0.006 & 0.008 & 0.005 \\
\hline $\mathrm{Ni}$ & 0.000 & 0.000 & 0.000 & 0.000 & $\mathrm{~K}$ & 0.000 & 0.000 & 0.000 & 0.000 & 0.000 & 0.000 \\
\hline $\mathrm{Cr}$ & 0.000 & 0.000 & 0.001 & 0.000 & $\Sigma$ & 7.992 & 7.987 & 8.020 & 8.010 & 8.021 & 8.016 \\
\hline$\Sigma Y$ & 2.896 & 2.873 & 2.913 & 2.965 & & & & & & & \\
\hline \multirow[t]{2}{*}{ Yvak. } & 0.104 & 0.127 & 0.087 & 0.035 & Prp & 11.80 & 6.93 & 11.80 & 12.29 & 12.29 & 23.30 \\
\hline & & & & & Alm & 76.81 & 63.08 & 52.33 & 53.92 & 37.61 & 66.17 \\
\hline $\mathrm{Ca}$ & 0.065 & 0.285 & 0.102 & 0.118 & Uv & 0.09 & 0.00 & 0.03 & 0.00 & 0.03 & 0.00 \\
\hline $\mathrm{Na}$ & 0.543 & 0.581 & 0.811 & 0.753 & Grs & 5.73 & 27.17 & 30.54 & 30.29 & 5.62 & 1.66 \\
\hline K & 0.003 & 0.005 & 0.000 & 0.000 & Sps & 5.57 & 2.82 & 2.41 & 2.05 & 41.32 & 6.47 \\
\hline$\Sigma X$ & 0.611 & 0.871 & 0.913 & 0.871 & $A d r$ & 0.00 & 0.00 & 2.90 & 1.46 & 3.13 & 2.39 \\
\hline X vak. & 0.389 & 0.129 & 0.087 & 0.129 & & & & & & & \\
\hline$F$ & 0.000 & 0.000 & 0.000 & 0.000 & & & & & & & \\
\hline $\mathrm{Cl}$ & 0.002 & 0.005 & 0.000 & 0.000 & & & & & & & \\
\hline
\end{tabular}


Tab. 2. Continued

\begin{tabular}{|c|c|c|c|c|c|c|c|}
\hline mineral & Cr-spl & & & & Mag & & \\
\hline sample & $M O-1 A$ & $M O-1 C$ & & & $M O-1 A$ & $M O-1 C$ & \\
\hline & in $\mathrm{Hbl}$ & $1 c$ & $1 r$ & & $1 c$ & $1 c$ & $1 r$ \\
\hline $\mathrm{SiO}_{2}$ & 0.09 & 0.07 & 0.03 & & 0.01 & 0.03 & 0.12 \\
\hline $\mathrm{TiO}_{2}$ & 0.72 & 2.74 & 2.65 & & 0.04 & 13.94 & 0.87 \\
\hline $\mathrm{Al}_{2} \mathrm{O}_{3}$ & 3.57 & 11.84 & 11.86 & & 0.10 & 0.01 & 0.07 \\
\hline $\mathrm{Fe}_{2} \mathrm{O}_{3}$ & 23.04 & 9.37 & 9.87 & & 67.50 & 38.17 & 62.30 \\
\hline $\mathrm{FeO}$ & 27.54 & 17.72 & 20.50 & & 31.06 & 42.36 & 30.04 \\
\hline $\mathrm{MnO}$ & 1.81 & 0.33 & 0.33 & & 0.04 & 0.12 & 0.00 \\
\hline $\mathrm{MgO}$ & 0.07 & 9.31 & 7.48 & & 0.00 & 0.00 & 0.00 \\
\hline $\mathrm{CaO}$ & 0.29 & 0.00 & 0.00 & & 0.01 & 0.02 & 0.03 \\
\hline $\mathrm{Cr}_{2} \mathrm{O}_{3}$ & 37.34 & 44.99 & 43.53 & & 0.03 & 0.00 & 0.01 \\
\hline $\mathrm{K}_{2} \mathrm{O}$ & 0.00 & 0.00 & 0.00 & & 0.00 & 0.00 & 0.00 \\
\hline $\mathrm{Na}_{2} \mathrm{O}$ & 0.00 & 0.00 & 0.00 & & 0.00 & 0.00 & 0.00 \\
\hline $\mathrm{NiO}$ & 0.00 & 0.17 & 0.18 & & 0.00 & 0.00 & 0.00 \\
\hline $\mathrm{ZnO}$ & 0.90 & 0.07 & 0.08 & & 0.00 & 0.00 & 0.00 \\
\hline $\mathrm{V} 2 \mathrm{O}_{5}$ & 0.24 & 0.22 & 0.20 & & 0.20 & 0.06 & 0.05 \\
\hline$\Sigma$ & 95.61 & 96.83 & 96.71 & & 98.98 & 94.72 & 93.48 \\
\hline $\mathrm{Si}$ & 0.003 & 0.002 & 0.001 & & 0.000 & 0.001 & 0.005 \\
\hline $\mathrm{Ti}$ & 0.021 & 0.070 & 0.069 & & 0.001 & 0.420 & 0.027 \\
\hline $\mathrm{Al}$ & 0.163 & 0.476 & 0.483 & & 0.005 & 0.000 & 0.003 \\
\hline $\mathrm{Fe}^{3+}$ & 0.671 & 0.240 & 0.257 & & 1.976 & 1.152 & 1.929 \\
\hline $\mathrm{Fe}^{2+}$ & 0.892 & 0.505 & 0.593 & & 1.010 & 1.420 & 1.033 \\
\hline $\mathrm{Mn}$ & 0.059 & 0.010 & 0.010 & & 0.001 & 0.004 & 0.000 \\
\hline $\mathrm{Mg}$ & 0.004 & 0.473 & 0.386 & & 0.000 & 0.000 & 0.000 \\
\hline $\mathrm{Ca}$ & 0.012 & 0.000 & 0.000 & & 0.000 & 0.001 & 0.001 \\
\hline K & 0.000 & 0.000 & 0.000 & & 0.000 & 0.000 & 0.000 \\
\hline $\mathrm{Na}$ & 0.000 & 0.000 & 0.000 & & 0.000 & 0.000 & 0.000 \\
\hline $\mathrm{Cr}$ & 1.143 & 1.212 & 1.190 & & 0.001 & 0.000 & 0.000 \\
\hline $\mathrm{Ni}$ & 0.000 & 0.005 & 0.005 & & & & \\
\hline $\mathrm{Zn}$ & 0.026 & 0.002 & 0.002 & & & & \\
\hline V & 0.006 & 0.005 & 0.005 & & 0.005 & 0.002 & 0.001 \\
\hline$\Sigma$ & 3.000 & 3.000 & 3.000 & & 3.000 & 3.000 & 3.000 \\
\hline Mg\# & 0.005 & 0.48 & 0.39 & Xusp & 0.00 & 0.42 & 0.03 \\
\hline $\mathrm{Cr} \#$ & 0.88 & 0.72 & 0.71 & Xmag & 1.00 & 0.58 & 0.97 \\
\hline
\end{tabular}

Note: $c$ - core, $r$-rim (periphery) of the grain. In magnetite $\mathrm{FeO}_{\text {tot }}$ is distributed between $\mathrm{FeO}$ and $\mathrm{Fe}_{2} \mathrm{O}_{3}$ sensu Dropp (1987).

hornblende and actinolite were identified in metabasic rocks of the other Tatric core mountains (e. g. Malé Karpaty Mts., Tribeč Mts.; Hovorka \& Kováčik 2007). Amphiboles from amphibolitic gneisses and amphibolites of the Dumbier crystalline complex correspond to Mg-hornblende, or they lie close to Fe-hornblende field
(Spišiak \& Pitoňák 1990; Fig. 6A). Despite of chromespinel inclusions in $\mathrm{Mg}$-hornblende, which could indicate the origin within the altered metaultramafites occur in the Dumbier crystalline complex (Spišiak \& Pitoňák 1990; Biely et al. 1992), we do not suppose this provenance because of these rocks have contained only 
tremolite (Spišiak et al. 1988). Similarly, primitive Mesozoic basalts cutting through the crystalline basement (Hovorka et al. 1982; Hovorka \& Spišiak 1988; Spišiak et al. 1991) could have represented a potential source of $\mathrm{Mg}$-hornblende with $\mathrm{Cr}$-spinel inclusions. However, amphiboles from these rocks are zonal and correspond to kaersutite or low-silicum kaersutite (l. c.). Actinolite and $\mathrm{Mg}$-hornblende occur in lenses of eclogite from the Dumbier crystalline complex which is overprinted in the granulite facies (Janák et al. 2009). Their textural features (symplectites with clinopyroxene and plagioclase, l. c.) do not suppose the amphibole genesis in eclogites. However, this possibility cannot be quite excluded.

Cr-spinel inclusions in amphibole (MO-1A, $\mathrm{MO}$ 1C samples) indicate the initial basic protolith of amphibole (basic volcanic or volcano-clastic rock). Ferritchromite inclusions in hornblende can be explained by protolith of amphibolitic rocks. It can be considered a mixture of basic volcanic (to $75 \%$ ) and terrigenous sedimentary (up to $25 \%$ ) materials (Pitoňák \& Spišiak 1988).

On the other hand, the source rock of hornblende could be the quartz diorite to diorite currently existing in the form of the enclaves in Prašiva type granitoids between Bôr (1887.6 $\mathrm{m}$ a.s.l.) and Jaloviarka (1428.6 $\mathrm{m}$ a.s.l.) (Fig. 2). The chemical composition of amphibole from diorite corresponds to Mg-hornblende with $\mathrm{Mg \#}=(0.73$ to 0.78$)$ and $\mathrm{Al}_{\text {tot }}=(0.844$ to 1.107 a.p.f.u.). Actinolite, $\mathrm{Mg}$-hornblende, tschermakitic hornblende and edenite are known from the identical rocks distributed in the other core mountains (Tatricum; Cambel et al. 1981; Uher \& Miko 1994; Ivanička et al. 1998; Fig. 6A). Diorites from the Dumbier crystalline complex contain an accessory pyroxene (Biely \& Bezák et al. 1997). However, pyroxene was neither observed in the heavy mineral assemblage obtained from the cave sediments nor recorded in the recent alluvium sediments of the Mošnica Stream (Bačo et al. 2004). Despite this, part of the Mg-hornblende can be attributed to diorite provenance, mainly hornblende having a lower content of $\mathrm{Ti}, \mathrm{Al}_{\text {tot }}$ and perhaps even $\mathrm{Na}_{2} \mathrm{O}$ (Fig. 6B-D).

Heterogenous composition and different types of garnet zonality were found in the various metamorphic rocks from the Dumbier crystalline complex (Spišiak \& Pitonák 1990). The garnets with higher spessartine content have been recorded in the Nízke Tatry crystalline basement. The garnets from granitoid rocks correspond to almandine with significant spessartine (up to $24 \mathrm{~mol}$. \% Sps; Petrík \& Konečný 2009). The highest $\mathrm{MnO}$ recorded from pegmatitic granites (up to $17 \mathrm{wt}$ \%) in the Prašivá massif (Broska et al. 2012). These rocks consider to the parental rocks of spessartine garnet found in MO-1C sample.
It follows that the accumulating area of palaeoflow (palaeoflows), which brought the material to the Mošnica Cave was formed mainly by the crystalline rocks - granitoids, gneisses and amphibolites. The specific proportion of the allochthonous material probably originates in the siliciclastics of the Lúžna Formation distributed on the crystalline basement. In crystalline rocks there were described the hydrothermal barite veins (Zuberec et al. 2005), whose presence we registered in the investigated samples (Tab. 1), too.

\section{IMPLICATIONS FOR THE PRE-QUATERNARY EVOLUTION OF THE CAVE AND SURROUNDING AREA}

Generally, we can conclude that the main source area of allochthonous material of the Mošnica Cave was from the south non-carbonate part of the Mošnica Valley, probably also the metamorphic rocks despite the current position of the metamorphic crystalline complex behind the main ridge of the Nízke Tatry Mts. (cf. Biely et al. 1992). The contact of metamorphic rocks and granitoids is indeed tectonic (Biely \& Bezák et al. 1997; Bezák \& Biely 1998).

A fluvial transport of allochthonous material into the cave is probably linked with a past larger catchment area of the allogenic karst of Mošnica Valley on the preQuaternary less dissected terrain.

Bella $(1988,2001)$ supposed the formation of the Mošnica Cave during the Late Pliocene (synchronously with the formation of surrounding planation surface which remnants are currently at about $1000 \mathrm{~m}$ a.s.l.). Orvoš and Orvošová (1996) assumed that the Mošnica Cave was formed between 3.2-2.588 Ma. Paleomagnetic record proved the deposition of the cave sediments took place during the Pliocene period (Kadlec et al. 2004). In the Western Carpathians the Late Pliocene is considered as a period of tectonic stability with the formation of the river level (Mazúr 1963; Lukniš 1964 and others).

The transport of the clastic material from metamorphic rocks (enriched in amphibole), recently exposed behind the ridge of the mountain range on the southern slopes of the Nízke Tatry Mts., performed probably during the pre-Pliocene period. In this time the metamorphic complex occurred in the northern slopes. A change of watershed boundary leaded through the central range of the Nízke Tatry Mts. can be explained by the tilting of the core mountain around the horizontal or subhorizontal axis (Grecula \& Roth 1978) towards the north, in the compression regime during the Late Tertiary (Kovác 2000; Plašienka 2003). The uplift of the Nízke Tatry crystalline basement was induced by transpressional tectonic regime in the Lower Miocene (Kováč et al. 1994; Kováč 2000 and others). The relatively rapid uplift of mountain 


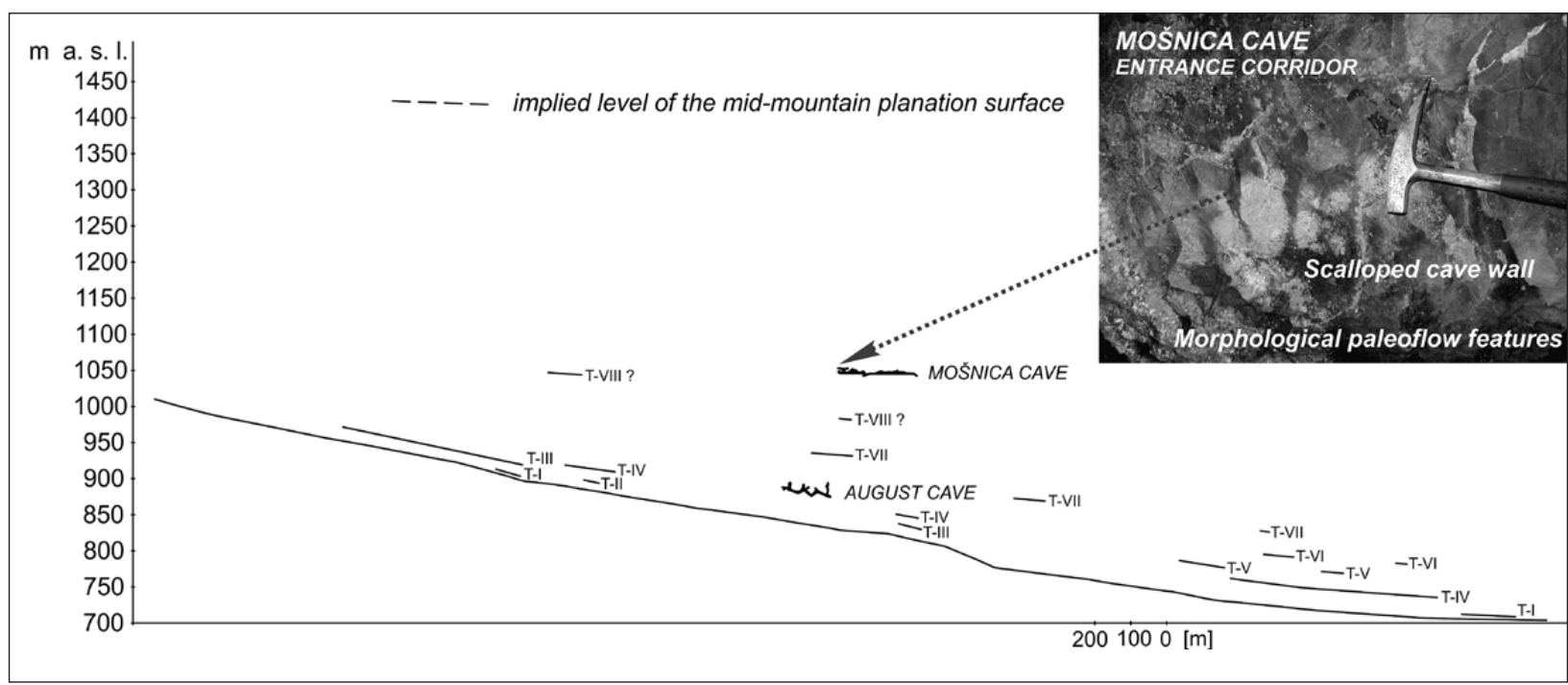

Fig. 7: Longitudinal sections of relief evolution levels in the middle and northern parts of the Mošnica Valley (Bella 1988) including horizontal and subhorizontal caves, and remnants of Pleistocene river terraces T-I to T-VIII.

range occurred over the last stages of its development (Halmešová et al. 1992).

The remnant of scalloped rock wall in the Entrance Corridor is a morphological indicator of water flow into the continuing cave parts from the lower entrance (Bella \& Urata 2002). This is an evidence of fluvial transport of the allochthonous material into the cave. In accordance with the considerations of Bella (1988) as well as Bella and Urata (l. c.) the underground spaces of the Mošnica Cave was primary originated by water flow with the involvement of the Mošnica palaeoflow. The treatment of the heavy mineral grains and their mineralogical character indicate a close source. The oldest allogenic river network in the Nízke Tatry Mts. elevation confirms the occurrence of the allochthonous sediments in the Ohnište paleokarst (Orvošová et al. 2006).

Based on the age of allochthonous sediments older than 2,588 Ma (Bosák et al. 2004; Kadlec et al. 2004) and their relation with remnants of planation surfaces and river terraces in the valley (Fig. 7) as well as the position of main horizontal cave corridors (at 1,055-1,060 m a.s.l.) in a relative height of $220 \mathrm{~m}$ above the recent river bed in the Mošnica Valley, the Mošnica Cave was originated during the pre-Quaternary period, probably in the Pliocene. On the northern part of the Nízke Tatry Mts. remnants the mid-mountain planation surface (Sarmatian-Early Pannonian) are at 1,400-1,450 m a.s.l., the submountain pediment (Pontian?) at 1,225-1,250 m a.s.l. and the river pediment (Late Pliocene) mostly at 1,000-1,050 m a.s.l. (Bella 2002). The relief of the area during a phreatic and epiphreatic development of the cave by allogenic waters was lesser dissected than in the recent.

Droppa (1950) assumed an aeolian transport of allochthonous material on the surface above the Mošnica Cave mainly from Bôr (1887.6 $\mathrm{m}$ a.s.l.) and its subsequent washing into the cave by seeping meteoric waters. Based on follow up investigations we tend towards its fluvial transport into the cave by flood waters from a surfaced allogenic paleostream that were slow-moving and ponded mostly in the Loamy Corridor. On the territory of the northern part of Paratethys the warm-temperate humid climate during the Pliocene was not favourable for aeolian processes and appertaining landform sculpturing.

\section{CONCLUSIONS}

1. Translucent heavy mineral assemblages reflect no provenance changes.

2. The main source area of the Mošnica Cave was I-type granitoids and probably also the metamorphic rocks despite the current position of the metamorphosed crystalline complex behind the main ridge of the Nízke Tatry Mts.

3. The remnant of scalloped rock wall in the Entrance Corridor (Bella \& Urata 2002) and sedimentary features of studied allochthonous sediments indicate 
their fluvial transport into the Mošnica Cave. Paleomagnetism research of the sediments (Kadlec et al. 2004) and the relative high of the cave above the recent flood plain indicate that the cave originated during the pre-Quaternary period (Pliocene) when a surface morphology (river network) was lesser dissected than the recent relief.

4. The transport of the clastic material from metamorphic rocks performed probably during the prePliocene period, seeing that during Pliocene a tectonic stability in the Nízke Tatry Mts. is considered. In the prePliocene period, the metamorphic complex occurred in the northern slopes.

Acknowledgements. This work was supported by the Slovak Research and Development Agency under contract APVV-0625-11 and APVV-0081-10. Digital graphics of the figure $1 \mathrm{~A}$ was processed by $\mathrm{M}$. Gallay. We are grateful to Pavel Bosák and anonymous reviewer for constructive comments on this paper.

\section{REFERENCES}

Aubrecht, R., 1994: Heavy mineral analyses from "Tatric" units of the Male Karpaty Mountains (Slovakia) and their consequences for Mesozoic Paleogeography and tectonics.- Mitt. Österr. Geogr. G., 86, 121-132.

Bačo, P., Bačová, N., Bakoš, F., Fodorová, V., Derco, J., Dzurenda, Š., Hricová, M., Hvoždara, P., Kovaničová, L., Križáni, I., Lučiviansky, P., Ondíková, H., Repčiak, M. \& J. Smolka, 2004: Reinterpretation of heavy-mineral concentrates exploration in Slovakia (in Slovak). MŽP SR, ŠGÚDŠ, pp. 119, Bratislava.

Bella, P., 1988: Speleological research of the Mošnica Valley karst (in Slovak).- Slovenský kras, 26, 87-112.

Bella, P., 2001: To the paleogemorphic development of fluviokarst caves in the Demänová Hills (in Slovak).- Geomorphologia Slovaca, 1, 54-63.

Bella, P., 2002: To the reconstruction of planation surfaces in the Demänová Hills on the northern side of the Nízke Tatry Mts. (in Slovak).- Geographia Slovaca, $18,13-20$.

Bella, P., Hercman, H., Gradziński, M., Pruner, P., Kadlec, J., Bosák, P., Głazek, J., Gąsiorowski, M. \& T. Nowicki, 2011: Geochronology of cave levels in the Demänová Valley, Nízke Tatry Mts. (in Slovak).Aragonit, 16, 64-68.

Bella, P. \& K. Urata, 2002: On the paleohydrografical development of the Mošnica Cave (in Slovak).- Slovenský kras, 40, 19-29.

Bezák, V. \& A. Klinec, 1983: The new interpretation of tectonic development of the Nízke Tatry Mts. West part.- Geologický Zborník Geologica Carpathica, 31, 569-575.

Bezák, V. \& A. Biely, 1998: Geological-tectonic setting of the Dumbier part of the Nízke Tatry Mts., parallelism with the study by D. Andrusov et al. (1951).Mineralia Slovaca, 30, 1, 81-82.
Bezák, V., Polák, M., Konečný, V. (eds.), Biely, A. Elečko, M., Filo, I., Hók, J., Hraško, L., Kohút. M., Lexa, J., Madarás, J., Maglay, J., Mello, J., Olšavský, M., Pristaš, J., Siman, P., Šimon, L., Vass, D. \& J. Vozár, 2008: General geological map of Slovak Republic at a scale 1:200,000; Map sheet 36 - Banská Bystrica.MŽP SR, ŠGÚDŠ, Bratislava.

Biely, A. (ed.), Beňuška, P., Bezák, V., Bujnovský, A., Halouzka, R., Ivanička, J., Kohút, M., Klinec, A., Lukáčik, E., Maglay, J., Miko, O., Pulec, M., Putiš, M. \& J. Vozár, 1992: Geological map of the Nizke Tatry Mts. at a scale 1: 50 000.- SGÚ - GÚDŠ, Bratislava.

Biely, A., Bezák, V. (eds.), Bujnovský, A., Vozárová, A., Klinec, A., Miko, O., Halouzka, R., Vozár, J., Beňuška, P., Hanzel, V., Kubeš, P., Liščák, P., Lukáčik, E., Maglay, J., Molák, B., Pulec, M., Putiš, M. \& M. Slavkay, 1997: Explanations to the Geological map of the Nizke Tatry Mts. at a scale 1:50,000 (in Slovak).GSSR, pp. 232, Bratislava.

Bosák, P., Pruner, P., Kadlec, J., Hercman, H. \& P. Schnabl, 2004: Paleomagnetic research of sedimentary fills of selected caves in Slovakia (in Czech). Etapová zpráva č. $4 \mathrm{MS}$, Geologický ústav AV ČR, pp. 405, Praha.

Bosch, R. F. \& W. B. White, 2004: Lithofacies and transport of clastic sediments in karst aquifers.- In: Sasowsky, I. D. \& J. Mylroie (eds.) Studies of Cave Sediments. Kluwer Academic, pp. 1-22, New York.

Bónová, K., Hochmuth, Z. \& J. Derco, 2008: Preliminary results from mineralogical study of fluvial sediments in the Skalistý potok Cave (Slovak Karst) (in Slovak).- Slovenský kras, 46, 277-286. 
Bónová, K., Bella, P., Kováčik, M., Bóna, J., Petro, L., Kollárová, V. \& L. Kovaničová, 2014: Allochthonous fine-grained sediments and their relation to the genesis of Liskovská Cave (Chočské Foothills, northern Slovakia) (in Slovak).- Acta Geologica Slovaca, 6, 2, 145-158.

Broska, I. \& I. Petrík, 1993: Tonalite of the Sihla type s. 1.: a Variscan plagioclase-biotite I-type magmatite in the Western Carpathians (in Slovak).- Mineralia Slovaca, 25, 1, 23-28.

Broska, I. \& P. Uher, 2001: Whole-rock chemistry and genetic typology of the West-Carpathian Variscan granites.- Geol. Carpath., 52, 2, 79-90.

Broska, I. \& I. Petrík, 2011: Accessory Fe-Ti oxides in the West-Carpathian I-type granitoids: witnesses of the granite mixing and late oxidation processes.- Miner. Petrol., 102, 1-4, 87-97.

Broska, I., Petrík, I. \& P. Uher, 2012: Acessory mineralsof the Carpathian granitic rocks (in Slovak).- VEDA, pp. 235, Bratislava.

Bujnovský, A., 1975: Mesozoicum of the northern slopes of the Nízke Tatry Mts. (the area between Križianka and Lupčianka) (in Slovak).- Vlastivedný zborník Liptov, 3, 83-102.

Cambel, B., Medved', J. \& P. Pitoňák, 1981: Geochemie und Petrogenese dioritischer Gesteine der Kleinen Karpaten.- Geologický Zborník Geologica Carpathica, 32, 189-220.

Deer, W. A., Howie, R. A. \& J. Zussman, 1992: An Introduction to the Rock-Forming Minerals. Longman, 2-nd. Edition, pp. 696, London.

Dinev, L., 1942: Morphology of the Central Western Carpathians (in Bulgarian).- Izvestija na Bulgarskoto geografsko družestvo, 9, Sofija.

Dropp, G. T. R., 1987: A general equation for estimating $\mathrm{Fe}^{3+}$ concentrations in ferromagnesian silicates and oxides from microprobe analyses, using stoichiometric criteria.- Mineral. Mag., 51, 431-435.

Droppa, A., 1950: Mošnica Cave in the Nízke Tatry Mts. (in Slovak).- Krásy Slovenska, 27, 5-8, 182-193.

Droppa, A., 1966: The correlation of some horizontal caves with river terraces.- Studies in Speleology, 1, 186-192.

Droppa, A., 1972: Geomorphological settings of the Demänová Valley (in Slovak).- Slovenský kras, 10, 9-46.

Droppa, A., 1973: Review of investigated caves in Slovakia (in Slovak).- Slovenský kras, 11, 111-157.

Farahat, E. S., 2008: Chrome-spinels in serpentinites and talc carbonates of the El Ideid-El Sodmein District, central Eastern Desert, Egypt: their metamorphism and petrogenetic implications.- Chemie der Erde, 68, 193-205.
Fejdiová, O., 1977a: Development of the Lower Triassic clastics in the Central West Carpathians.- Geologický Zborník Geologica Carpathica, 28, 167-176.

Fejdiová, O., 1977b: Pre-Triassic weathering crust on the Liptovská Lúžna locality (Nízke Tatry Mts.) (in Slovak).- Mineralia Slovaca, 9, 4, 299-302.

Fejdiová, O., 1989: Pre-Triassic weathering crust on the Baláže locality (Nízke Tatry Mts.) (in Slovak).- Regionálna Geológia Západných Karpát, 25, 161-163.

Gillieson, D., 1996: Caves: Processes, Development and Management.- Blackwell, pp. 324, Oxford.

Grecula, P. \& Z. Roth, 1978: Kinematic model of the Western Carpathians in complete cuts (in Czech).Sborník geologických věd - geologie, 32, 49-73.

Gross, P., Köhler, E., Papšová, J. \& P. Snopková, 1980: Geology and stratigraphy of the inner-Carpathian Paleogene sedimentary rocks (in Slovak).- In: Gross, P., Köhler, E. (eds.) et al. Geológia Liptovskej kotliny. GÚDŠ, pp. 22-72, Bratislava.

Halmešová, S., Holzer, R., Marušiaková, D. \& L. Pospíšil, 1992: Geodynamic analysis of the Nízke Tatry Mountains based on geophysical and remote sensed data.- Sborník geologických věd, užitá geofyzika, $25,67-81$.

Henry, D. J. \& C. V. Guidotti, 1985: Tourmaline as a petrogenetic indicator mineral: An example from the staurolite-grade metapelites of NW Maine.Am. Mineral., 70, 1-15.

Hlaváč, J., Zimák, J. \& J. Štelcl, 2004: “Cave soils” in the show caves of the Nízke Tatry Mts. and Belianske Tatry Mts.- In: Bella, P. (ed.) Výskum, využivanie a ochrana jaskýn̆, zborník referátov zo 4. vedeckej konferencie, $5^{\text {th }}-8^{\text {th }}$ October 2003, Tále, 89-94, Liptovský Mikuláš.

Hovorka, D., Chovan, M. \& J. Michálek, 1982: Olivine fenokersantite in granodiorite country rock from Dúbrava, Nízke Tatry Mts.- Mineralia Slovaca, 14,1, 85-90.

Hovorka, D. \& J. Spišiak, 1988: Mesozoic volcanism of the Western Carpathians (in Slovak).- VEDA, pp. 225, Bratislava.

Hovorka, D. \& M. Kováčik, 2007: Occurence modes and types of amphibole in Pre-Tertiary metamorphic rocks of the Western Carpathians.- Mineralia Slovaca, 39, 269-282.

Ivanička, J., Hók, J., Polák, M., Határ, J., Vozár, J., Nagy, A., Fordinál, K., Pristaš, J., Konečný, V., Šimon, L., Kováčik, M., Vozárová, A., Fejdiová, O., Marcin, D., Liščák, P., Macko, A., Lanc, J., Šantavý, J. \& V. Szalaiová, 1998: Explanations to the geological map of the Tribec Mts. at a scale 1:50,000 (in Slovak).GSSR, pp. 247, Bratislava. 
Janák, M., Mikuš,T., Pitoňák, P. \& J. Spišiak, 2009: Eclogites overprinted in the granulite facies from the Dumbier Crystalline Complex (Low Tatra Mountains, Western Carpathians).- Geol. Carpath., 60, 3, 193-204.

Kadlec, J., Pruner, P., Hercman, H., Chadima, M., Schnabl, P. \& S. Šlechta, 2004: Magnetostratigraphy of sediments preserved in caves located in the Nízke Tatry Mts. (in Czech).- In: Bella, P. (ed.) Výskum, využívanie a ochrana jaskýn̆, zborník referátov zo 4. vedeckej konferencie, $5^{\text {th }}-8^{\text {th }}$ October 2003 , Tále, 15-19, Liptovský Mikuláš.

Kicińska, D. \& J. Głazek, 2005: Heavy minerals in deposits of Belianska Cave (in Polish).- In: Gradziński, M. \& M. Szelerewicz (eds.) Materialy 39. Sympozjum Speleologicznego, $7^{\text {th }}-9^{\text {th }}$ October 2005, Starbienino, p. 34, Kraków.

Korikovsky, S. P., Dupej, J., Boronikhin, V. A. \& N. G. Zinovieva, 1988: Zoned garnets and their equilibria in mica schists and gneisses of Kohút crystalline complex, Hnúšta region, Western Carpathians.Geologický Zborník Geologica Carpathica, 41, 2, 99-124.

Koutek, P., 1931: Geological studies on north-western side of the Nízke Tatry Mts.- Sborník Státního geologického Ústavu ČSR, oddelení geologie, 9, 413527.

Kováč, M., Král, J., Márton, E., Plašienka, D. \& P. Uher, 1994: Alpine uplift history of the Central Western Carpathians: geochronological, paleomagnetic, sedimentary and structural data.- Geol. Carpath., $45,83-96$.

Kováč, M., 2000: Geodynamic, paleogeographic and structural development of the Carpatho-Pannonian region during the Miocene: new view on the Neogene basins of Slovakia (in Slovak).- VEDA, pp. 202, Bratislava.

Kretz, R., 1983: Symbols of rock-forming minerals.- Am. Mineral., 68, 277-279.

Leake, B. E., Wooley, A. R., Arps, C. E. S., Birchs, W. D., Gilbert, M. C., Grice, J. D., Hawthorne, F. C., Kato, A., Kisch, H. J., Krivovichev, V. G., Linthout, K., Laird, J., Mandarino, J. A., Maresch, W. V., Nickel, E. H., Rock, N. M. S., Schumacher, J. C., Smith, D. C., Stephenson, N. C. N., Ungaretti, L., Whittaker, E. J. W. \& Guo Youzhi, 1997: Nomenclature of amphiboles: report of the Subcommittee on Amphiboles of the International Mineralogical Association, Commission on New Minerals and Mineral Names.Can. Mineral. 35, 219-246.
Lenaz, D., Kamenetsky, V. S., Crawford, A. J. \& F. Princivalle, 2000: Melt inclusion in detrital spinel from the SE Alps, (Italy-Slovenia): a new approach to provenance studies of sedimentary basins.- Contrib. Mineral. Petr., 139, 6, 748-758.

Lukniš, M., 1964: Remains of older surfaces of relief planation in the Czechoslovakian Carpathians (in Slovak).- Geografický časopis, 16, 3, 289-298.

Mazúr, E., 1963: Žilina Basin and the adjacent mountains (in Slovak).- SAV, pp. 184, Bratislava.

Méres, Š. \& D. Hovorka, 1991: Alpine metamorphic recrystallization of the pre-Carboniferous metapelites of the Kohút crystalline complex (the Western Carpathians).- Mineralia Slovaca, 23, 5-6, 435-442.

Miš́í, M. \& J. Jablonský, 2000: Lower Triassic quartzites of the Western Carpathians: transport directions, source of clastics.- Geol. Carpath., 51, 4, 251-264.

Morton, A., Hallsworth, C. \& B. Chalton, 2004: Garnet composition in Scottish and Norwegian basement terrains: a framework for interpretation of North Sea sandstone provenance.- Mar. Petrol. Geol., 21, 393-410.

Orvoš, P. \& M. Orvošová, 1996: Age estimation of the horizontal levels of caves in the Jánska Valley by means of their parallelisation to Váh River terraces (in Slovak).- In: Lalkovič, M. (ed.) Kras a jaskyne - výskum, využívanie a ochrana, zborník referátov $z$ vedeckej konferencie, $26^{\text {th }}-29^{\text {th }}$ September 1995 , Liptovský Mikuláš, 95-101, Liptovský Mikuláš.

Orvošová, M., Uhlík, P. \& P. Uher, 2006: Paleokarst of the Ohnište Plateau - research on the filling of the Velký závrt Doline (Nízke Tatry, Mts., Slovakia) (in Slovak).- Slovenský kras, 44, 71-80.

Petrík, I., Broska, I., Lipka, J. \& P. Siman, 1995: Granitoid allanite-(Ce): substitution relations, redox conditions and REE distributions (on an example of I-type granitoids, Western Carpathians, Slovakia).Geol. Carpath., 46, 79-94.

Petrík, I., \& P. Konečný, 2009: Metasomatic replacement of inherited metamorphic monazite in a biotitegarnet granite from the Nízke Tatry Mountains, Western Carpathians, Slovakia: Chemical dating and evidence for disequilibrium melting.- Am. Mineral., 94, 957-974.

Pitoňák, P. \& J. Spišiak, 1988: Simple model of paragneisses and amphibole rocks protoliths of the Nízke Tatry Mts. crystalline complex.- Geologický Zborník Geologica Carpathica, 39, 73-86.

Pitoňák, P. \& J. Spišiak, 1989: Mineralogy, petrology and geochemistry of the basic rock types from crystalline basement of the Nizke Tatry Mts. (in Slovak).Archív ŠGÚDŠ, pp. 232, Bratislava. 
Plašienka, D., 2003: Development of basement-involved fold and thrust structures exemplified by Tatric-Fatric-Veporic nappe system of the Western Carpathians (Slovakia).- Geodinamica Acta, 16, 21-38.

Powers, M. C., 1953: A new roundness scale for sedimentary particles.- J. Sediment. Petrol., 23, 117-119.

Spišiak, J., Pitoňák, P. \& M. Petro, 1988: Metaultramafites from the Jasenie-Kyslá area, the Low Tatras (in Slovak).- Mineralia Slovaca, 20, 2, 143-148.

Spišiak, J. \& P. Pitoňák, 1990: The Nízke Tatry Mts. crystalline complex - new facts and interpretation (Western Carpathians, Czechoslovakia).- Geologický Zborník Geologica Carpathica, 41, 4, 377392.

Spišiak, J., Arvensis, M., Linkešová, M., Pitoňák, P. \& F. Caňo, 1991: Basanite dyke in granitoids near Dúbrava, Nízke Tatry Mts., Central Slovakia (in Slovak).- Mineralia Slovaca, 23, 339-345.
Stevens, R. E., 1944: Composition of some chromites of the Western Hemisphere.- Am. Mineral., 29, 1-34.

Škvaček, A., 1978: Glaciation of the Mošnica Valley in the Nízke Tatry Mts. (the Western Carpathians).AFRNUC, Geographica, 16, 177-190.

Uher, P. \& O. Miko, 1994: Biotite-amphibole (mela)tonalite - quartz diorite in the Žiar Mts. (Western Carpathians, Slovakia) (in Slovak).- Mineralia Slovaca, 26, 365-366.

Xuan Thanh, N., Trong Tu, M., Itaya, T. \& S. Kwon, 2011: Chromian-spinel compositions from the Bo Xinh ultramafics, Northeern Vietnam: Implications on tectonic evolution of the Indochina block.- J. Asian Earth Sci., 42, 258-267.

Zuberec, J., Tréger, M., Lexa, J. \& P. Baláž, 2005: Mineral resources of Slovakia.- ŠGÚDŠ, pp. 350, Bratislava. 